\title{
GALATA SERPUŞ HAN ve TAVAN RESIMLERI
}

\author{
$20 \%$ \\ SERPUȘ HAN IN GALATA AND CEILING PAINTING
}

Veli BAÇARU*

\begin{abstract}
$\underline{\ddot{O}_{\mathbf{z}}}$
Bu çalışma, İstanbul, Beyoğlu İlçesi'nde yer alan Serpuş Han'1 iki yönden ele almaktadır. Bunlardan birincisi, hanın plan düzeni, cephe kuruluşları gibi mimari özellikleri ile bina dışında bulunan süsleme unsurları; ikincisi ise birinci katındaki iki odanın tavanında aynalı tonozların ayna kısmına gelecek şekilde uygulanan biri elips, diğeri dikdörtgen formlu iki tavan resmidir. Yapının, Perşembe Pazarı Caddesi yönünde birinci kattaki bir penceresinin kemer aynasında sıva ile işlenen kitabesinde H. 1148 (M. 1735-36) tarihi verilmiştir. Han bir sıra taş, iki sıra tuğla şeklinde almaşık düzende ve kâgir olarak inşa edilmiştir. Zemin üzerinde iki kat olmak üzere üç katlı olan yapı bu yönüyle 18. yy.'da üç katlı olarak inşa edilen birkaç handan biridir. Han, zemin kat seviyesinde dikdörtgen planl, birinci ve ikinci katta ise U planlı bir biçimlenişe sahiptir. Han'ın güney yönünde, zemin kat seviyesinde bir duvarla sınırlandırılmış, içinde üst kata çıkan merdivenin bulunduğu ve avlu olarak değerlendirilebilecek küçük bir alan mevcuttur. Yapının birinci ve ikinci katında U planlı, sivri kemerli, avluya açılan revak yapıyı sarmaktadır. Eserin cephelerinde gönye tipi çıkmalar yer alırken, almaşık duvar ve tuğla dekorasyon taklidi sıva uygulamaları cephelerde görülmektedir. Bu çalışmada çeşitli kaynaklara yansıyan bilgiler ile elde edilen veriler üzerinden eser yeniden değerlendirmiştir.
\end{abstract}

Anahtar Kelimeler: Şehiriçi hanları, İstanbul, Perşembe Pazarı, tavan resimleri, Galileo

\section{$\underline{\text { Abstract }}$}

This study is dealing with two aspect of Serpuş Han, which is located in Beyoğlu district of İstanbul. The first of these is that architectural features, including the plan features of the building and decorative elements of the facade. The second one is ellipse and rectangular ceiling paintings that situated in the mirror part of the vaults on the ceiling of the two rooms on the first floor. 1148 H (1735-36 A.D.) date is given in the inscription of a window on the first floor of the building, which was processed with plaster in the arch mirror. Han was built a order stone and two order of bricks in alternatively. The building is three floors including ground and two floors. Han this feature with is one of the with rare buildings built in the 18th century. It has a rectangular plan on the ground level and U plan on the first and second floors. There is a small area which can be considered a courtyard which bounded by a wall the ground floor level. There is in a staircase leading up to the

\footnotetext{
* Sanat Tarihçisi, İstanbul. Doktorant, Ege Üniversitesi, Sanat Tarihi Bölümü, İzmir.

ORCID ID: 0000-0002-3427-4638 • E-mail: velibacaru@gmail.com
} 
upper floors in this area. On the first and second floors of the building, the U-shaped, pointed arch, and the porch that opens into the courtyard surrounds the building. There are miter-type protrusions on the facades of the building, while alternating or brick decoration imitation plaster applications are seen on the facades. In this study, the Han is re-evaluated based on the information obtained from various sources and the data.

Key Words: City khans, inn, İstanbul, Perşembe Bazaar, Ceiling paintings, Galileo

\section{Giriş}

Bu çalışmanın amacı, Galata'da bulunan Serpuş Han'ın ${ }^{1}$ plan, cephe ve süsleme özelliklerini ele almak ve Han'ın birinci katında bulunan iki tavan resmini tanıtmak; aynı zamanda eserin plan, cephe ve süsleme özelliklerine dair kaynaklara yansıyan bilgileri elde edilen yeni bilgilerle beraber değerlendirmektir.

Bu yapıyla ilgili çalışmalar sınırlıdır. İstanbul hanları üzerine Ceyhan Güran'ın hazırladığı çalışmada ${ }^{2}$ eser katalog bölümünde incelenmiştir. Yapının doğrudan ele alındığı tek kaynak ise Gönül Cantay'ın yazdığı ansiklopedi maddesidir. ${ }^{3}$ Bunun yanında İstanbul'da bulunan 18. yy. hanlarının cepheleri üzerine hazırlanan bir yüksek lisans tezinde eser cephe kuruluşu yönünden değerlendirilmiştir. ${ }^{4}$ Yine İstanbul hanları ile ilgili veya İstanbul'la ilgili çeşitli çalışmalarda ${ }^{5}$ sınırlı düzeyde bilgilerle bu handan bahsedilmektedir.

Serpuş Han, bugün Beyoğlu İlçesi sınırlarında kalan tarihi Galata bölgesinde, Arap Cami Mahallesi, Perşembe Pazarı Caddesi üzerindedir. ${ }^{6}$ Hanın kuzeyinde Voyvoda Caddesi'ni geçince Saint Pierre Kilisesi ve Hanı, daha kuzeyde Galata Kulesi, sahil tarafında Saksı Han, biraz daha aşağıda Fatih Bedesteni ve yapının batı tarafında ise Arap Cami gibi bölgenin önemli yapıları bulunmaktadır. Yine tarihi kimliği olan çok sayıda bina, özellikle Perşembe Pazarı Caddesi üzerinde görülebilmektedir.

Hanın yer aldığı Galata bölgesinin, İlkçağ’dan itibaren yerleşime sahne olduğu ve Sykai ismiyle anıldığı belirtilmektedir. ${ }^{7}$ Bu bölge I. Constantin tarafından surla çevrilmiş

1 Serpuş, "başa giyilen her tür libas (giysi) ve kisve" olarak tanımlanmaktadır. Bk. Arseven, 1975, 1739.

2 Güran, 1976.

3 Cantay, 1994, 552.

4 Bilecik,1998.

5 Fidan, 2009, 55; Ceco, 2012, 140-141; Erksan, 1956; Benli, 2007. (Erksan'ın çalışması İstanbul Hanları üzerinedir ancak Serpuş Han'a değinilmemiştir. Benli'nin tez çalışması sadece tarihi yarımadadaki hanları kapsamaktadır.)

6 Eser, Beyoğlu imar planına göre 1472 Ada ve 61, 62, 63, 64, 65 numaralı parseller üzerindedir.

7 Eyice, 1968, 86. 
ve II. Teodosios zamanında şehrin bölgelere ayrılmasıyla XIII. bölge olmuştur. ${ }^{8}$ Bölgede Cenevizliler'in ilk ne zaman yerleştikleri net olmamakla birlikte 13. yy. içlerinde Galata bölgesine yerleştikleri ve Galata Kulesi'nin bulunduğu alanın Ceneviz imtiyaz bölgesine 1349 'da ilave edilmesi ile burada bir kulenin yapıldığ kaydedilmektedir.'

12. yy.'da Haliç'in kıyısında bir imtiyaz bölgesine sahip olan Cenevizliler dördüncü Haçlı seferinden sonra imtiyazlarını Venedikliler'e kaptırmıştır. 1260 sonrası Bizans'ın Latinler'e üstünlük sağlaması ile belli imtiyazlar tanınan Cenevizliler'in sur yapmalarına izin verilmemiştir. $\mathrm{Bu}$ yüzden çeşitli saldırılara maruz kaldıkları

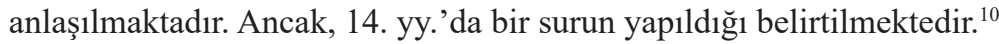

Fetihten sonra Galata'da Rum mahallelerinin Ceneviz yerleşmesinin etrafına toplanmış durumda olduğu, Fatih Sultan Mehmed'in vakıfları ile kurulan alt yapı sonrasında Türk nüfusun bölgede Rum nüfustan sonra ikinci kalabalık grup haline geldiği belirtilmektedir. Türk mahallelerinin Azapkapı ile Hisariçi arasındaki boş alana kurulduğu kaydedilmektedir. Yine İspanya'dan gelen Yahudi ve Müslümanların bölgenin demografik yapısına etkileri olduğu da belirtilen bir diğer husustur. ${ }^{11}$ Arap Camii çevresine gayr-1 Müslimler'in inşaat yapmalarına ve oturmalarına izin verilmediği bazı arşiv kayıtlarından anlaşılmaktadır. ${ }^{12}$

Uzun yıllar Cenevizlilerin etkili olduğu bölgeye, 1540’tan sonra Venediklilerin taşındığ 1 kaydedilmektedir. ${ }^{13} 17$ ve 18 . yy.'da Fransa ile ilişkilerin gelişmesi, tanınan bazı imtiyazlarla beraber Fransız, İngiliz ve Fransız bayraklı bazı Avrupa ülkelerinin Galata' daki yoğunluğunun arttığı anlaşılmaktadır. ${ }^{14} 18$. yy. gezgini olan İnciciyan'a göre Galata'da, ağırlıklı olarak Ermeni, Rum ve Avrupalıların yaşadığı, bunun yanında bir miktar Türk ve Yahudi'nin bulunduğu belirtilmektedir. Değerlendirilen bir diğer husus da Perşembe Pazarı tarafında Avrupalıların ikamet ettiğidir. ${ }^{15}$ Perşembe Pazarı'ndaki üç Latin kilisesi bu yargıyı desteklemektedir.

19. yy.'da Galata'nın ardındaki açık alanlara doğru yerleşimin arttığı, Pera'daki bağ alanlarında yapılaşmaların görüldüğü, Galata bölgesinin ise ağırlıklı olarak Fransız, İngiliz, İtalyan sanayici ve tüccarların, ülkelerinden getirdikleri malların indirilip, depolanıp satıldığı bir alana dönüştüğü kaydedilmiştir. ${ }^{16}$

8 Eyice, 1969, 11.

9 Eyice, 1969, 11-12.

10 Eyice, 1969, 11-12.

11 Ortayl1, 1996, 303-304.

12 Refik, 1988, 30,31.

13 Ağır, 2009, 96.

14 Kömürciyan, 1988, 35; Bulunur, 2014, 83-85; Horoz, 2019, 144-145.

15 İnciciyan, 1956, 83, 86; 18. yüzyıl sonlarındaki Galata ve kiliseleri için $b k$. Carbognano, 1993, 73-79.

16 Akın, 1998, 99. 
20. yy. başlarında İstanbul'da bulunan B. Bareilles'in Galata'ya dair gözlemleri ve yorumlarından, özellikle Galata Kulesi'nin dibi olarak ele alınan bölgenin Fransız semti olarak nitelendirildiği öğrenilmektedir. Burada iki yüz ya da üç yüz yıllık bir dönemde gelişen Colbert ticaretinin ${ }^{17}$ sürdürüldüğü cumbalı, alçak ve basık yapılı hanların varlığından bahsedilmekte ve bu hanların hâlâ ayakta olduğunu belirtmektedir. Bunun yanında dönemin şartlarına uygun olarak nitelediği Fransız konutlarının ise kale görünümlü, paslı demir parmaklıklı az sayıda pencereli evleri ve birkaç ahşap saçaklı dükkânı ile XIII. Louis dönemi yapılarını çağrıştırdığını ifade etmektedir. ${ }^{18}$ Beylié, 1903 tarihli çalışmasında, içinde Serpuş Han'ın da bulunduğu yapıların Ceneviz yapisı olduğundan bahsetmektedir. ${ }^{19}$

Arseven, Galata üzerine yaptığ1 çalışmalarda bölgedeki mimari doku üzerine değerlendirmelerde bulunmaktadır. İçinde Serpuş Han'ın da bulunduğu ve Perşembe Pazarı Caddesi civarında yer alan yapıların Bizans Dönemi'ne ait olduklarından söz ederken, inşa tarihleri belli olmadığından bazılarının 14. yy.'dan sonra ve 17. yy.'dan önceki tarihlerde inşa edildiklerini ve üslup özellikleri itibariyle Ceneviz mimarisi ile benzerlikleri olduğunu kaydetmektedir. ${ }^{20}$ Arseven bir başka çalışmasında, Per-

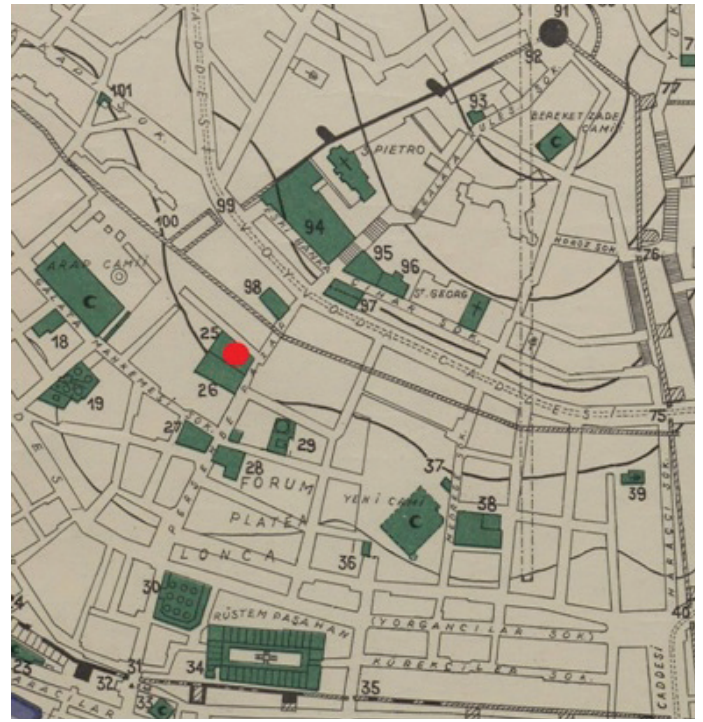

Şek. 1: Schneider ve Nomadis'in 1944 tarihli Galata Topographisch-Archaologischer Plan'ında Serpuş Han'in Yeri. (https://www.flickr.com/)
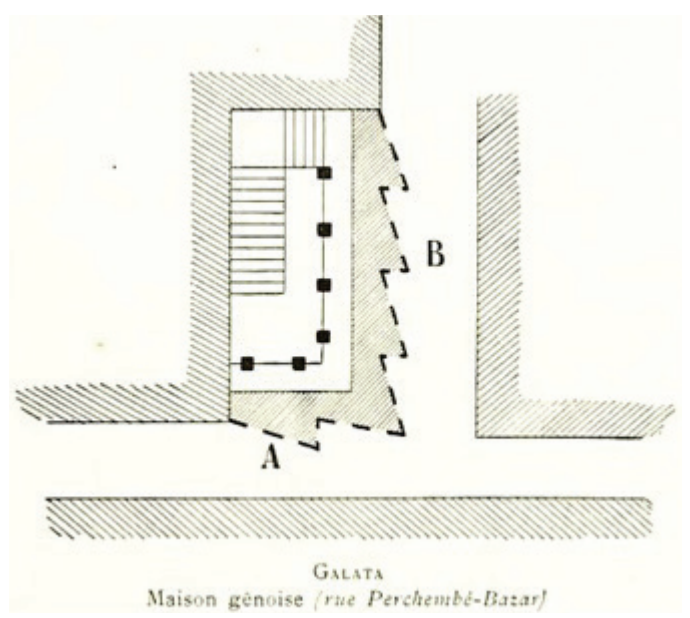

Şek. 2: 20. Yy. Başında, Hanın Konumunu Gösteren Kroki (Beylié, 1903, 17.)

17 Colbert ticaretinin Osmanlı'ya yansımaları hakkında bk. Kallek, 2000, 242-245.

18 Bareilles, 2003, 52.

19 Beylié, 1903, 17.

20 Arseven, 1989a, 79. 
şembe Pazarı civarı, Eski Osmanlı Bankası binasının alt kısımlarında bazı sokaklarda Bizans Dönemi evleri ve dükkânlarına dair bir dokunun olduğunu belirtmektedir. ${ }^{21}$ Arseven'in tarifinden anlaşıldığı kadarıyla, bahsettiği ev ve dükkânların, Perşembe Pazarı Caddesi üzerinde yer alan ve içinde Serpuş Han'ın da bulunduğu kâgir yapılar olduğu düşünülmektedir. Evliya Çelebi de Galata’yı ele alırken denizden Kule Kapısı'na kadar Cenevizliler' in kâgir yapıları olduğundan bahsetmektedir. ${ }^{22}$

Serpuş Han'ın ticaret yapısı mı olduğu, yoksa konaklama işlevine mi sahip olduğu bilinmemektedir. Apartmanlar üzerine hazırladığı çalışmasında Öncel, Serpuş Han'la birlikte Perşembe Pazarı'ndaki bazı yapıları apartmanların erken örnekleri olarak ele almaktadır. ${ }^{23}$ Eserin zemin katının depolama, üst kat odalarının konaklama ve/veya işyeri/büro olarak da kullanılma durumu söz konusudur. Ancak 19. yy. sonlarında hanın ticari amaçlı olarak kullanıldığı anlaşılmaktadır. ${ }^{24}$ Bununla birlikte, hanın, F. Akozan'ın Vezir Hanı (1659-60), Büyük Yeni Han (1763-64), Çuhacı Han (18. yy.) gibi örnekler verdiği ve Evliya Çelebi'ye atıfta bulunarak hâcagân hanları olarak nitelediği, odaları büro olarak kullanılan hanlardan ${ }^{25}$ olduğunu düşünmekteyiz.

\section{Serpuş Han}

Han, Perşembe Pazarı Caddesi ile Eski Tay Çıkmazı'nın kesiştiği alanda, meyilli bir araziye kurulmuştur. Zemin üzerine iki kat olmak üzere, üç katlı inşa edilmiştir. Han planlama itibariyle zemin katta dikdörtgen, birinci ve ikinci katta ise "U" plan arz etmektedir. (Şek. 3, 4, 5.) Hanın güney ve batı yönlerinde cepheleri başka yapılarla bitişik nizamda iken kuzey ve doğu cepheleri açık durumdadır.

Hanın inşa tarihi ve banisi bilinmemekle birlikte, Perşembe Pazarı Caddesi tarafında birinci kat pencerelerinden en güneydekinin kemer aynasında sıva ile kabartma şeklinde yazılmış H 1148 (1735-36) tarihi yer almaktadır. ${ }^{26}$ Bu tarihin, binanın inşa tarihi mi yoksa geçirdiği bir onarımdan mı kaldığı saptanamamakla beraber, yapıda başka bir kitabeye rastlanmamıştır. Eser, cephe kuruluşu ve malzeme özellikleri bakımından 18 . yy.' da inşa edilen hanlarla benzer özellikler sergilemektedir. ${ }^{27}$

İstanbul'daki hanların yer aldığı 1821 tarihli bir belgede yapının ismi geçmemektedir. ${ }^{28} 1885-1914$ yılları arasında handaki odaları kullanan kişilerin isimlerini

21 Arseven, 1989b, 66.

22 Evliya Çelebi, 2003, 393. Galata'daki kule kapıları ve surları hakkında bkz.: Kuş, 2009.

23 Öncel, 2010, 103-117.

24 Fidan, 2009, 55.

25 Akozan, 1963, 137.; Ersoy, 1994, 75-97.

26 Bazı kaynaklarda bu tarihin, eserin inşa tarihi olarak alındığı anlaşılmaktadır. Bk. Ortaylı, 1996, 306; Bilecik, 1998, 41.

27 Güran, 1976, 132.

28 Yaşar, 2014, 511-524. 
ve odaların ne amaçla kullanıldığını ele alan bir çalışmada, ${ }^{29}$ faaliyet alanları itibariyle; 2 komisyoncu, 3 tüccar, 2 antikacı, 3 kitapçı, 1 litograf, ${ }^{30} 1$ desinatör, 1 işadamı, 1 sobac1, 1 elektrikçi, 1 kolonya imalatçısı, 1 bayan konfeksiyoncusu, 1 kumaşçı şeklinde bir dağılım verilmektedir.

Hanın zemin kat seviyesinde, Perşembe Pazarı Caddesi'ne bakan cephede altı, Eski Tay Çıkmazı Sokağı'na bakan cephede on adet olmak üzere altlı ve üstlü düzende iki sıra penceresi bulunmaktadır. Alt sıradaki pencereler daha dar ve lentolu iken üst sıradaki pencereler daha geniş ve yuvarlak kemerlidir. İki sırada da söve, kemer ve lentolarda taş malzeme kullanılmıştır. Alt sıra pencereleri sivri kemer alınlıklıdır. Hanın zemin katında üç kapı bulunmaktadır. Bunlar; Eski Tay Çıkmazı'nda bulunan ve hanın girişinin sağlandığı basık kemerli kapı ile bunun yanında benzer özellikler gösteren ve dikdörtgen planlı geniş mekana girişi sağlayan kapı ile Perşembe Pazarı Caddesi'nde, köşeye yakın konumda, caddeye paralel uzanan mekana girişin sağlandığı lentolu kapıdır. Cadde yönünde zemin katta alt sıra pencereleri, kemer seviyesinin altından itibaren açılarak dikdörtgen formlu bir kapı olacak şekilde yenilenmiştir. Burada üçü pencere hizasında ve biri de kapı hizasında olmak üzere dört dükkan bulunmaktadır. Bu yeni kapıların açıldığı ve caddeye paralel uzanan mekan, hafif malzeme ile bölünerek ayrı dükkanlar şeklinde düzenlenmiştir.

Hana, Eski Tay Çıkmazı üzerinde yer alan geniş ve basık kemerli bir açıklıktan girilmekte, (Fot. 4) bu girişten beşik tonoz örtülü dar bir koridor geçilerek, üst katlara çıkan merdivenin yer aldığı küçük bir avluya ulaşılmaktadır. Beşik tonozlu koridorun bitiminde sağdaki köşe pahlanmıştır. Koridorda solda geniş bir kapıdan geçilerek Perşembe Pazarı Caddesi'nden de bir girişi bulunan, caddeye paralel uzanan tonozlu mekana geçiş basık kemerli bir kapı ile verilmiştir. Koridorun sağında ise geniş, sivri kemerli bir niş yer almaktadır. Hem koridorun devamında hem de avluda merdivenlerin hemen yanında, yakın zamanda yapılmış ekler bulunmaktadır. (Fot. 5, 8.) Avluda üst katlara geçişi sağlayan merdivenlerin üzerine oturtulduğu alanda, geniş bir kemerin iki yanında küçük tonozlu mekanlar vardır.

Zemin katta, Eski Tay Çıkmazı üzerinde, hanın asıl girişinin yanında ve girişi ona benzer şekilde basık kemerli bir kapı ile sağlanan, sokağa dik, dikdörtgen planlı ve beşik

29 Fidan, 2009, 55. Bu çalışmada odaları işleten esnaflardan ikisi dışındakilerin Ermeniler'den ve Avrupalılar'dan oluştuğu görülmektedir.

30 Litograf ile ilgili Osmanlı Arşivi'ndeki bir belgede “Galata'da Perşembe Pazarı'nda Serpuş/ Seryuş Han'ı derununda on iki numaralı odada taş ve hurufatla ilanat ve kart döviziyet misüllü evrak tab 'etmek üzere bir matba 'a küşad edeceğinden bahisle ruhsat-ı resmiyenin itast istidasına dair teba-i Devlet-i Aliyye'den ve mücellid esnafindan ve Mihal imzastyla verilen arzuhal leffen irsal kılınmıştır. Merkum ile küşad edeceği matbaa hakkında muamele-i nizamiyenin icrasıyla neticesinin işarı hususunun Matbuat-ı Dahiliye idaresi ifadesiyle beyanına ibtidar kılındı ol babda" şeklinde ifade edilen kayıtta hanın 12 numaralı odasında taş baskı yoluyla kart, ilan, döviz baskısı yapılacak matbaaya dair verilen dilekçeye istinaden ciltçi esnafından da görüş alınarak ruhsatlandırma sürecine dair bilgiler içermektedir. $b k$. T.C. Cumhurbaşkanlığı Devlet Arşivleri Bşk. - Osmanlı Arşivleri’nde DH. MKT, 2196/109, 23 Zilhicce 1316 (4 Mayıs 1899) 


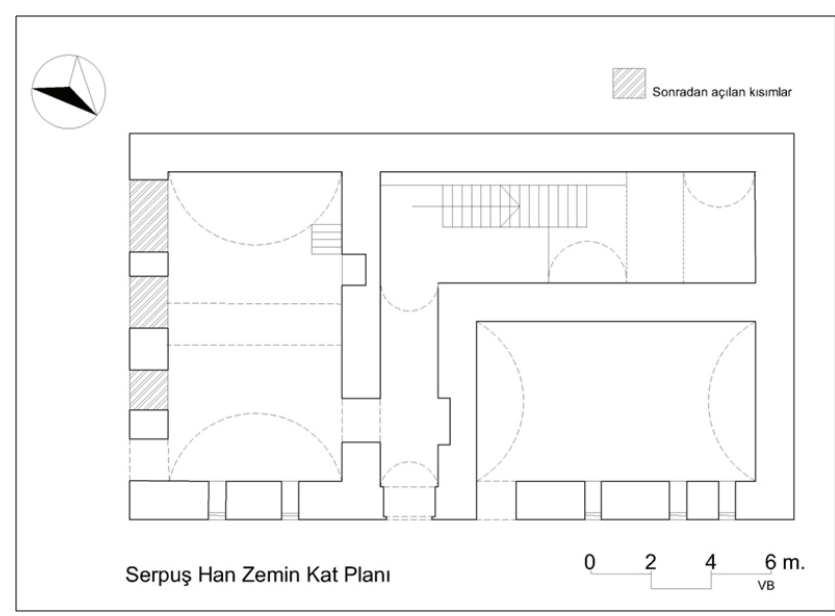

Şek. 3:

Serpuş Han

Zemin Kat Planı

(V. Baçaru)

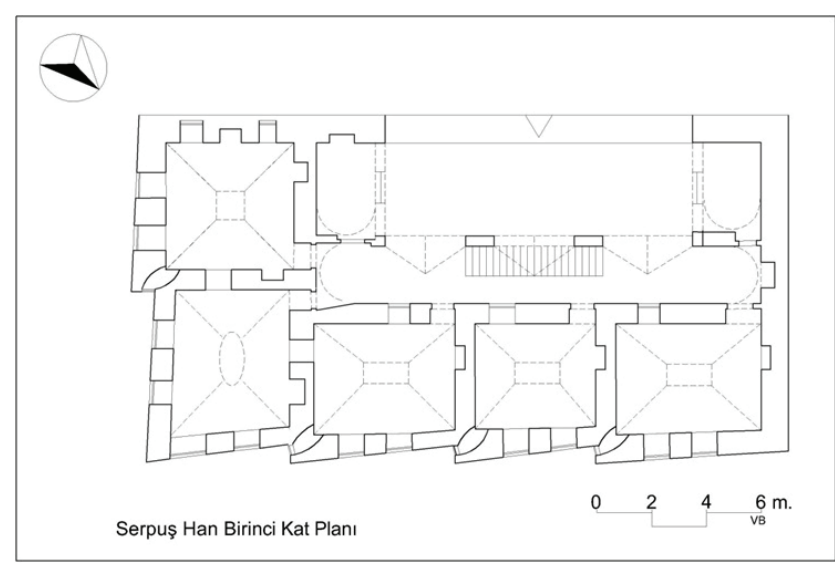

Şek. 4:

Serpuş Han

Birinci Kat Planı

(V. Baçaru)

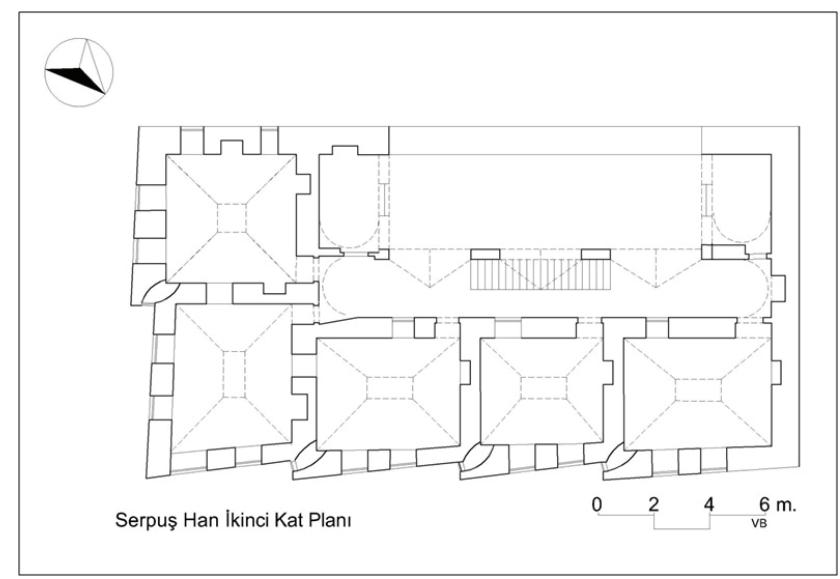

Şek. 5:

Serpuş Han

İkinci Kat Planı

(V. Baçaru) 


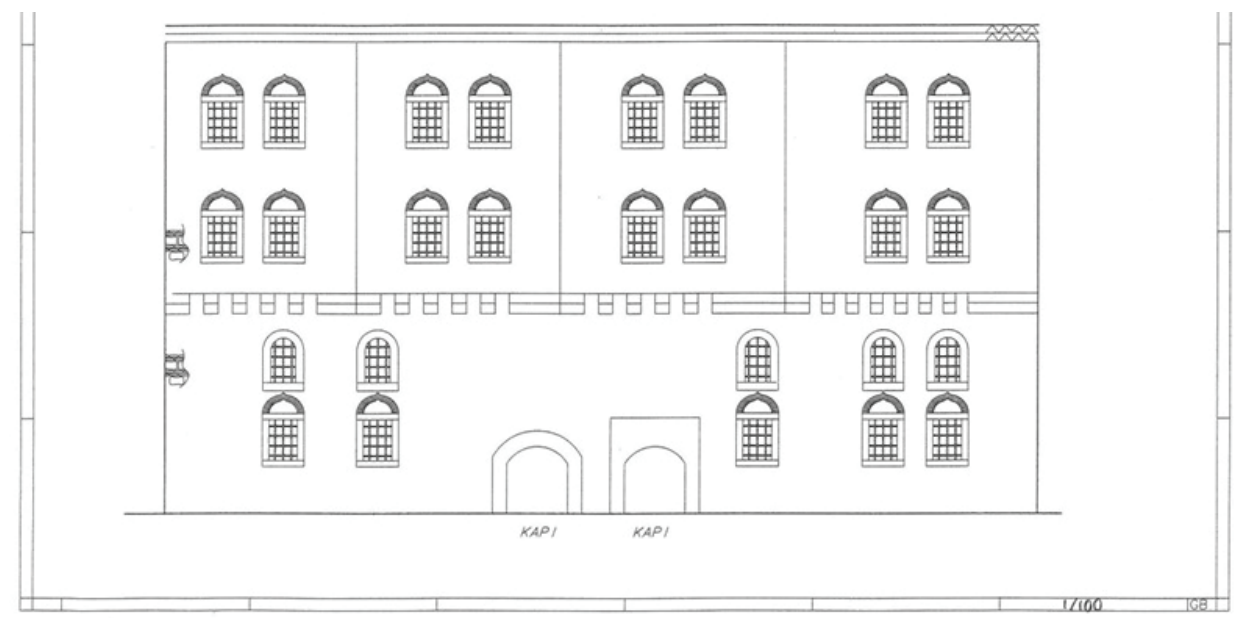

Şek. 6: Serpuş Han Giriş Cephesi Şeması. (Bilecik, 1998, ekte 143.)

tonozlu bir mekana girilmektedir. Kapıdan geçişte basamaklarla mekana inilmektedir. Bu mekanın iç kısmında tavana betonarme malzemeyle kirişler ve üzerine tabla beton atılmıştır.

Hanın birinci katına avludan tek kollu sahanlıklı merdivenle ulaşılmaktadır. Merdiven binayı "U” biçiminde saran revağa çıkmaktadır. (Fot. 7, 8; Şek. 4, 5.) Revaklar, U planın kol ve orta kısmında beşik tonoz örtülü olmakla beraber beşik tonozun karnına, avluya bakan sivri kemerli kısmın penetrasyon yaparak yedirilmesi şeklinde ele alınmıştır. (Fot. 10.) Sivri kemerli revaklar "U" düzeninin iki ucundaki kemerli kısımların önleri sonradan kapatılarak birer kapalı mekan haline getirilmiştir. (Fot. 8.) Revağın ortasından bir merdivenle ikinci kata çıkılmaktadır. Revaklı kısmın gerisinde dikdörtgen planlı beş oda vardır. Bu mekanlar manastır tonoz ile örtülüdür. Cadde tarafına bakan yüzdeki iki oda, biri köşede olmak üzere, yan yana iken diğer üç oda bu köşe odaya bitişik olup, Eski Tay çıkmazına paralel yerleştirilmiştir. Odalara kemerli, alçak kapılardan girilmektedir. Kapılar demirdendir. Perşembe Pazarı Caddesi tarafındaki iki oda dışındaki odalar birer pencere ile revağa bakmaktadır. Pencereler demir korkulukludur.

Yapının ikinci katı, plan ve yerleşim olarak birinci kata benzer bir düzene sahiptir. (Şek. 4, 5.) İkinci kattan, muhtemelen sonradan ilave edilmiş ve çatı katına çıkan merdiven bulunmaktadır.

Birinci kat ve ikinci kat cepheleri, çıkmaları ve pencere düzeni itibariyle benzer özelliklere sahiptir. (Şek. 6, 7, 8.) Binanın cadde tarafında iki, Eski Tay Çıkmazı tarafında dört olmak üzere, cephelerinde profilli taş konsollara bindirilmiş gönye tipi çıkmalar yer almaktadır. Gönye çıkmaların geniş kısmında, dar bir pencere bulunmaktadır. Bu dar pencere dışında her odada iki pencere vardır (Fot.15). Odalarda iç duvarlara nişler açılmıştır. 


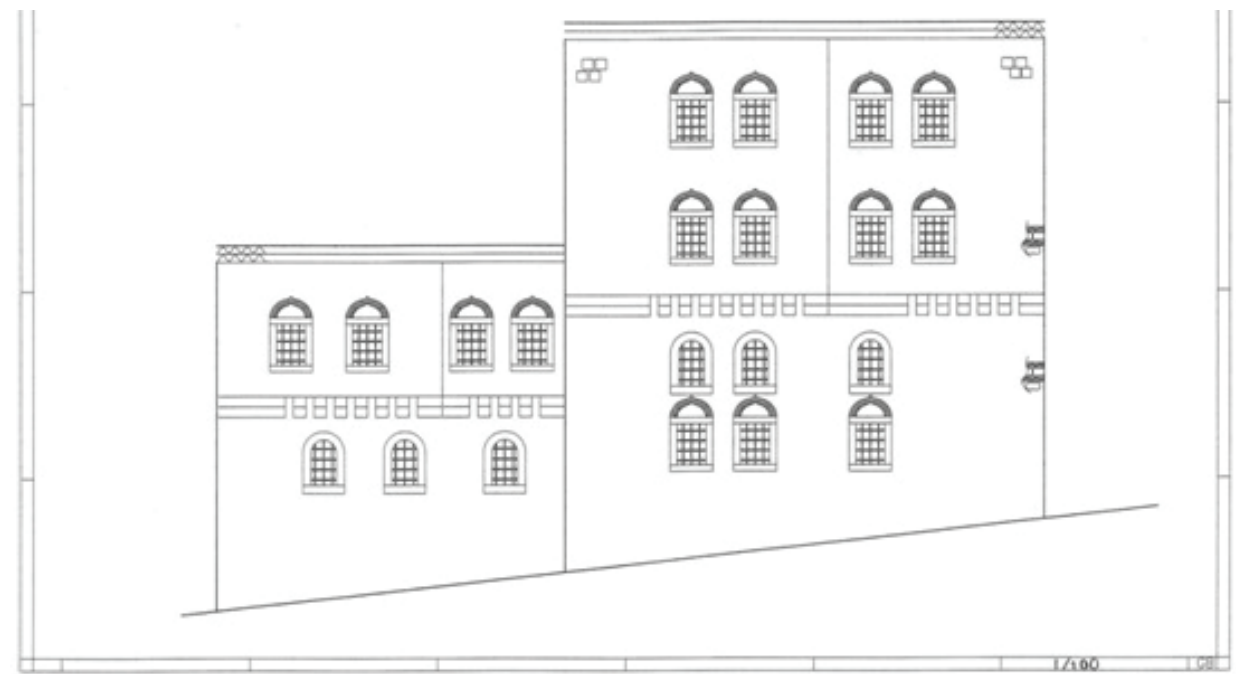

Şek. 7: Serpuş Han Perşembe Pazarı Cad. Tarafından Cephe Şeması. Yanındaki Bağımsız Binanın Cephesiyle Birlikte. (Bilecik, 1998, ekte 144.)

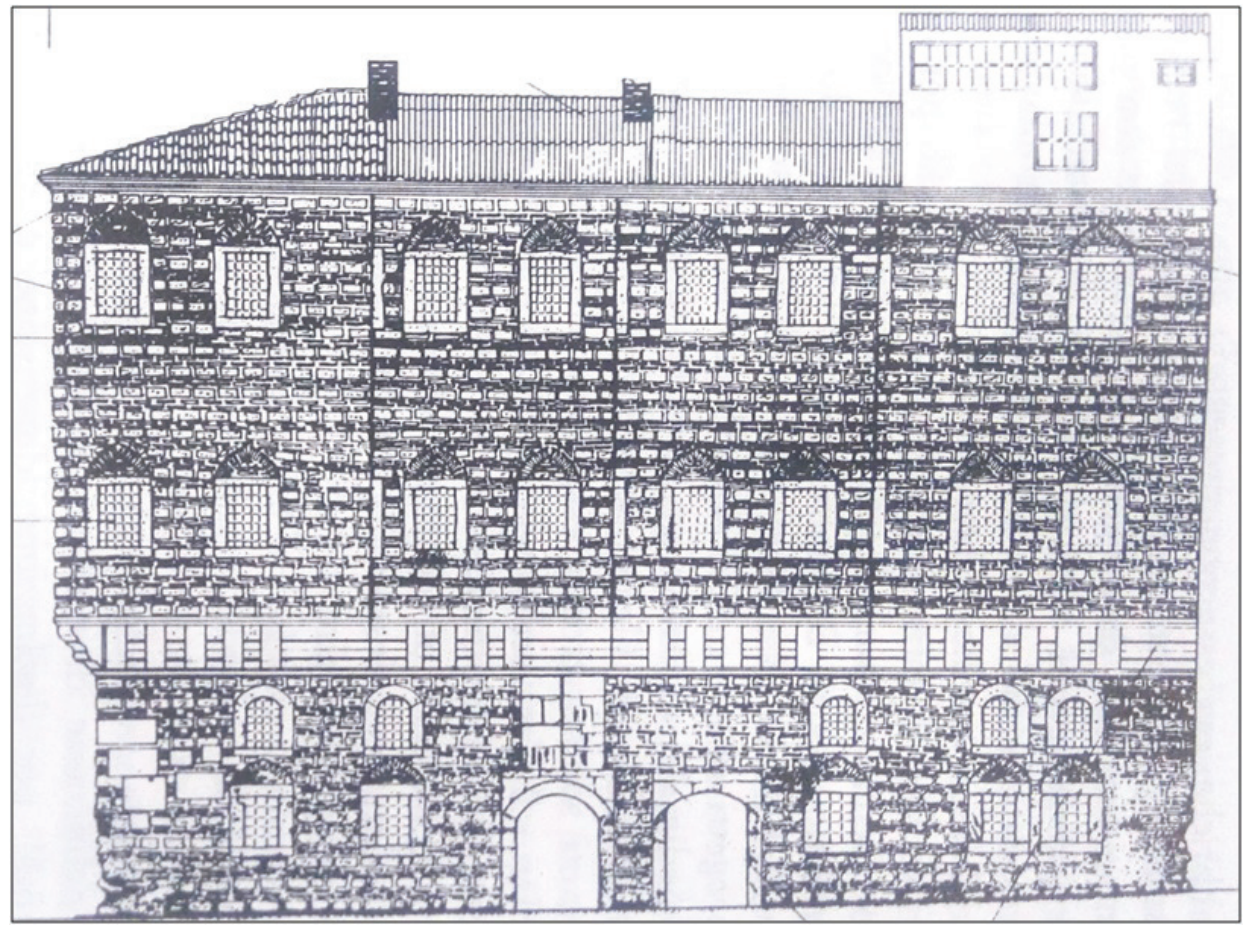

Şek. 8: Serpuş Han Giriş Cephesi, Görünüş (Cuneo, 1989, 59.) (Yayında D. D’Angelo'nun tezinden alındığ1 yazılıdır; ancak tezin künyesi verilmemiştir.) 
Hanın duvar örgüsü, bir uzun bir kısa olmak üzere iki sıra tuğla - bir sıra kaba yonu taş şeklinde almaşık düzendedir. Kısa tuğlalar ortalama $14.5 \mathrm{~cm}$, uzun tuğlalar 29 cm'dir. Bu almaşık örgünün üzerine kasetleme tekniği duvar örgüsü, sıva ile taklit edilerek uygulanmıştır. (Fot. 3, 33, 34.) Kemer alınlıkları da tuğlanın farklı istifi ile elde edilen motifler şeklinde sıvayla taklit edilerek kaplanmıştır. Kemer aynalarında merdiven formu, tuğlanın yatay ve dikey dizilmesi, yatay tuğla örgü gibi motifler işlenmiştir. (Fot. $16,17,18$.) Eserin beden duvarları kirpi saçak ile nihayetlenmektedir. Cephede, caddeye bakan yüzde, saçak seviyesinin altında güney ve kuzey köşelerde kuşevlerinin yerlerine dair izler bulunmaktadır. (Fot. 11.)

\section{Tavan Resimleri}

Resimler, hanın birinci katında, Perşembe Pazarı Caddesi'ne bakan tarafta, Galata Kulesi yönünde köşe odanın tonozunda ve bu odanın batısında, bitişiğindeki odanın tavanındadır. Resimlerin bulunduğu bu odalar aynalı tonozla örtülüdür. Köşe odadaki resim aynalı tonozun, ayna kısmına elips formunda profilli bir çerçeve içinde işlenmiştir. Yaklaşık olarak 80 x $164 \mathrm{~cm}$ boyutlarındadır. (Fot.19, 20.)

Resim, dökülen kısımlardan anlaşıldığı kadarıyla, düzleştirilmiş beyaz bir malzeme üzerine, olasılıkla alçı yüzeye yapılmıştır. Resmin etrafında elips biçimindeki profilli çerçevenin de aynı malzemeden üretildiği anlaşılmaktadır. Elips çerçevenin bir kenarında bir demir ucu görülmektedir. Çerçevenin içinde ve resmin uygulandığ1 tablada demir kullanılmış olması ve bu şekilde tavana tutturulmuş olması muhtemeldir. $\mathrm{Bu}$ ihtimal bize resmin tavanda yapılmadığını, uygun bir yerde yapıldıktan sonra aynalı tonozun yüzeyine tutturulduğunu düşündürmektedir. Resim incelendiğinde yapım tekniği açısından iki olasılık ortaya çıkmaktadır: Birinci olasılık resmin firça ile boyama yoluyla yapıldı̆̆ı, diğer olasılık ise taş baskı yoluyla yapıldı̆̆ıdır. Handa 19. yy. sonunda faaliyet gösteren kişi ve meslekleri içeren kaynaktan edinilen bilgiler arasında yapıda bir litograf dükkanının bulunduğu anımsanmalıdır. ${ }^{31} \mathrm{Bu}$, resmin taş baskı yoluyla yapılmış olabileceği düşüncesi uyandırmaktadır. Resimde siyah, gri ve füme renkleri tercih edilmiştir. Hanın eski bir fotoğrafindan, ${ }^{32}$ harap olduğu, dolayısıyla içinde yakılan ateşten çıkan duman ve isten resmin bu şekilde kararmış olabileceği de göz önünde tutulmalıdır.

Resmin merkezinde; bir sandalyede oturmuş, sağ bacağını sol bacağının üzerine atmış, sol kolunu bir sehpa üzerindeki iki kitabın üstüne koymuş ve sağ kolu ile açık durumdaki kitaba elindeki kalemle yazı yazan sakallı, boğumlu serpuşlu, krem rengi entarili, ayağında sandaletli bir figür oturmaktadır. Sağ elinde altı parmağının olduğu görülmektedir. Figürün fonunda iki yanda kitaplık resmedilmiştir. Kitaplıkların köşelerinde ion başlıklı birer sütun vardır. Sağdaki kitaplığın üzerinde ayaklı bir kase görülmektedir. Figürün tam arkasına gelecek şekilde bir dolap ve üzerinde karşıdan bakıldığında sağda teleskop solda ise açı̈̈lçer yer almaktadır. Figürün sağında, önde, enlem ve boylamları belirten kuşakların veya ekvator çizgisinin belirtildiği bir küre -dünya- bulunmaktadır.

31 Fidan, 2009, 55.

32 Fotoğraf için $b k$. Cornucopia, 2019. 
Resmin merkezindeki figürün gerisine doğru; zemin döşemeleri ve nesneler perspektif kurallarına uygun olarak ele alınmıştır. Ancak kompozisyonun önünde oda zemini kesilmiş, kompozisyon adeta dışarıdan bir gözle, oda içerisinden bir kesit sunar gibi resmedilmiştir. Betimin kesilmesiyle elips alanın alt kısmında bir boşluk elde edilmiş, burada bir armaya yer verilmiştir. Armada elips şeklinde bir gövde ve buna bitişik bir taç mevcuttur. Elips şeklindeki armanın arkasında kabza kısımlarında haç, "s" ve "c" kıvrımlı tasarımların olduğu, çaprazlama yerleştirilen ikişer kılıç vardır. Yine armanın altından dışa doğru taşan yapraklı, dallı bitkisel motifler işlenmiştir. Elips şeklindeki armanın üstüne, karşıdan bakıldığında solda bir Latin haçı, sağda ise çaprazlama iki kılıç ve bu kılıçların üstüne bir kuş figürü yerleştirilmiştir. Gövdenin üstündeki taç kısmında ortada, açık bir şekilde seçilemese de, kadeh motifi ve iki yanda birer insan figürü bulunduğu değerlendirilmektedir. (Fot. 27.)

Resme karşıdan bakıldığında, altta, armanın solundaki boş alanda, diyagonal pozisyonda bir imza veya yazı izi tespit edilmiştir. Ancak okunabilir durumda olmadığından, içeriği anlaşılamamıştır. (Fot. 27.)

İkinci tavan resmi, aynalı tonozun, ayna kısmını dolduracak şekilde dikdörtgen biçiminde yüzeye uygulanmıştır. (Fot. 30) İlk bakıldığında ahşap bir kap1 ve/veya pencere kanadı formuna benzer görüntü veren resim, kırılan ve çatlayan bölümlerinden anlaşıldığı kadarıyla alçıdan bu şekilde kalıplanmış ve ahşap rengi bir boyayla boyanmıştır. Ahşap görüntüsünü belirginleştirmek için, pencere ve kapı kanadındaki konturlar koyu renklerle vurgulanmıştır. Merkezde çökertme şeklinde eşkenar dörtgen ve köşelerde üçgen kartuşların yer aldığı bir düzene sahiptir. (Fot. 30, 32.) Eşkenar formun merkezinde, boyama yoluyla yapılmış barok karakterde, "s" ve "c" kıvrım dallı bir kompozisyon yer alırken üçgen köşe kartuşlarının içinde, net olmayan, yine boyama ile yapılmış dekoratif unsur bulunmaktadir. (Fot. 32.)

\section{Değerlendirme ve Sonuç}

Serpuş Han, tarihi Galata bölgesinde, Galata Kulesi'nin bulunduğu tepenin Haliç'e bakan yönünde ve geçmişte de Perşembe Pazarı olarak adlandırılan cadde üzerinde yer almaktadır. Çevresinde benzer inşa özellikleri gösteren Saksı Hanı [18. yy. (?)], İpçi (Ceneviz) Hanı (?) ve adları henüz bilinmeyen, iki katlı ve daha küçük boyutlu ancak benzer inşa özellikleri gösteren yapılar bulunmaktadır. Eski fotoğraflarda hanın hemen karşısında benzer özellikte, çıkmalı bir yapının yer aldığı anlaşılmaktadır. (Fot. 33.) Hanın kuzeyinde bölgenin önemli yapılarından biri olan Sen Piyer Hanı (1772) vardır. $\mathrm{Bu}$ nitelikler bölgenin ticarî karakterini ön plana çıkarmaktadır. Yine bazı arşiv belgelerinde Avrupa ülkelerinden ithal edilen ürünlerin bu bölgeye getirildiği görülmektedir. ${ }^{33}$ Fransızlar'ın kumaş, serpuş, şeker ve kağıt getirip karşılığında ürün aldıkları, 18. yy. ortalarında İstanbul'a gelen Venedik Senato Sekreterinin gözlemlerine

33 Kömürciyan, 1988, 35; Bulunur, 2014, 83-85; Horoz, 2001, 145. 
yansımıştır. ${ }^{34}$ Senato sekreterinin seyahat tarihinin, hanın cephesindeki tarih kitabesinden kısa bir süre sonraki 1742-1746 tarihleri arasını kapsaması ve serpuşun ithal edilen ürünler içerisinde olması, serpuşların bu hana nakledilmiş olabileceği ve isminin de buradan gelmiş olabileceği ihtimalini akla getirmektedir.

Hanın cephesinde sıva ile yazılı H 1148 (M 1735-36) tarihinin, yapının onarımından $\mathrm{m}$ kaldığı, inşa tarihini mi gösterdiği net değildir. Bir onarımdan kalma ihtimali ise, yapının verili tarihten önce var olduğunu muhtemel saymayı gerektirmektedir. Arşiv kayıtlarında hanla ilgili yeterli bilgiye ulaşılamamıştır. Bununla birlikte, 18. yy.'da inşa edilen Çuhacı Han (18. yy.) ve Büyük Yeni Han (1763-64) gibi yapılarda görülen kemer alınlıklarının tuğla veya çeşitli geometrik motiflerle kaplanmasının bu handa da görülmesi, yapının birçok kemer alınlığında bunun uygulanması, sıva ile işlenen tarihin inşa tarihi olabileceği ihtimalini güçlendirir. Yine eserin, iki katında da gönye tipi çıkma olması bakımından Büyük Yeni Han (1763-64) ve Yıldız Han (1817) ile ortak özellikler sergilediği görülmektedir. ${ }^{35}$

Han diğer İstanbul hanlarından farklı olarak tarihi hanlar bölgesinin dışında inşa edilmiştir. Ancak üç katlı oluşu, cephe düzeni, inşa malzeme ve tekniği gibi özellikler açısından aynı yüzyılda inşa edilen Büyük Yeni Han (1763-64) ile benzerlik gösterirken, ${ }^{36}$ Seyyid Hasan Paşa Hanı (1747), ${ }^{37}$ Atıf Efendi Kütüphanesi'nin meşruta binalarının cephe düzeni ve inşa malzemesi gibi boyutları ile ortak özellikler sergilemektedir. ${ }^{38}$ Bazı kaynaklarda Serpuş Han ve çevresindeki yapıların Cenevizler'den kalan binaların üzerlerine inşa edildikleri belirtilmektedir. ${ }^{39} \mathrm{Bu}$ ihtimal geçerli olsa bile binanın en azından birinci ve ikinci katları ile çıkmalarının, kitabede yer alan dönemde inşa edilmiş olabileceği ihtimalini güçlendirmektedir. Handaki birçok özellik, eserin bir 18. yy. yapısı olma ihtimalini desteklemektedir.

Serpuş Han ile biraz aşağısındaki Saksı Han ve İpçi (Ceneviz) Han'ın 19. yy.'da yaygınlaşan apartman yapılarının öncüleri olduğu belirtilmektedir. ${ }^{40}$ Ancak konumuz olan Serpuş Han'ın, avlulu ve revaklı oluşu, odalarının boyutu ve yerleşimi ile zemin katının ele alınışı ve diğer detayları, eserin bu özelikte olmadığını göstermektedir.

Çalışma konumuzu oluşturan Serpuş Han, C. Güran tarafından yakın bir konumdaki Saksı Han ve Yeni Cami Külliyesi’nin hemen yanında bulunan Şapçı Han'la ${ }^{41}$ birlikte "avlusuz hanlar" grubunda sayılmaktadır. Bu özelliği ile diğer iki hanla

34 Özkan, 2000, 285.

35 Ersoy,1994, 81.

36 Bk. Güran, 1976, 113-115.

37 Bk. Çobanoğlu, 2009, 60-62.

38 Kütüphane için $b k$. Eyice, 1991, 61.

39 Güran, 1976, 132-133.

40 Öncel, 2010, 103-117.

41 C. Güran, Şapçı Han’1 19. yy. eseri olarak ele almaktadır. Bk. Güran, 1976, 78. 
birlikte istisna olarak değerlendirilmektedir. ${ }^{42}$ Ancak hana girildiğinde dar bir koridor aşıldığında, üç yönde yapıyla, güney yönünde ise bir duvarla sınırlandırılmış küçük bir avluya ulaşılmaktadır. Birinci kat seviyesine kadar bir duvarla sınırlandırılmış bu alanda üst kata çıkan merdiven yer almaktadır. Duvarın ortasında tuğladan bir üçgen payanda bulunmaktadır. Tuğlaların boyutları itibariyle binada kullanılan şekliyle biri kısa biri uzun düzende olduğu ve bu şekilde istiflenerek örüldüğü görülmektedir.

C. Güran, yapıyı tanımlarken Perşembe Pazarı Caddesi’nde dört çıkma, Eski Tay Çıkmazı'nda ise iki çıkma olduğundan söz etmektedir. Bu çıkmaları taşıyan konsolların taştan ve iki sıra olduğunu kaydetmektedir. ${ }^{43}$ Ancak bu gönye tipi çıkmaların sayıları ve yerleri hakkında, mevcutta tersi bir durum söz konusudur. Eski Tay Çıkmazı'nda gönye tipi dört çıkma yer alırken Perşembe Pazarı Caddesi'nde gönye tipi iki çıkma bulunmaktadır. Güran ayrıca, zemin katta iki sıra halindeki pencerelerin arasında taş bir silme olduğundan bahsetmektedir. Ancak yine halihazırda bir taş silme mevcut değildir. (Fot. 3)

18. yy. İstanbul han cepheleri üzerine hazırlanan tezde ${ }^{44}$, hanın yola uydurulduğu ve eğimli bir araziye kurulduğu, Perşembe Pazarı Sokağı'nda dört testere dişi çıkmaya sahip olduğu, bunlardan yolun aşağısında olan ikisinin tek katlı ve diğer ikisinin ise yolun yukarısında olup iki katlı olduğu belirtilmektedir. Burada sözü edilen yolun aşağısında bulunan çıkmalar, Serpuş Han'ın bitişiğindeki başka bir hana aittir. Bitişiğindeki iki katlı yapı Serpuş Han'dan bağımsız, ayrı bir yapıdır. Her iki yapıda katların taban seviyeleri farklı kotlardadır. C. Güran'ın da bu cephedeki çıkma sayısını dört olarak ele alması benzer bir yaklaşımın doğmasına yol açmış olabilir. Ancak Güran, Eski Tay Çıkmazı'ndaki dört çıkmayı da iki çıkma olarak belirtmiştir. Bitişiğindeki hanla Serpuş Han'ın cephe düzenleri ve inşa malzeme ile teknik boyuttaki özellikleri paralellik göstermektedir. İki hanın yakın zaman dilimlerinde inşa edilme olasılığını yüksek ihtimal olarak değerlendirmekteyiz.

Hanın cephelerinde kasetleme tekniği sıvayla taklit edilerek, alttaki almaşık duvar örgüsünün üzeri kaplanmıştır. Yine kemer alınlıklarında tuğlanın farklı dizilmesiyle elde edilen geometrik motifler sıvayla taklit edilmiştir. 18. yy.'da inşa edilen Çuhacı Han ve Büyük Yeni Han (1763-64) gibi ticaret yapılarının yanında, Cağaloğlu'nda bulunan Hacı Beşir Ağa Camii ve Kütüphanesi (1744-45) gibi yapılarda da bu şekilde, almaşık duvar ve tuğla dekorasyonun sıva ile taklit edildiği uygulamalar mevcuttur. ${ }^{45}$

Eliptik bir çerçeve içinde bir bilginin çalışma ortamında tasvir edildiği resim, apartmanlar hakkındaki bir yayında görsel olarak sunulmuştur. ${ }^{46}$ Bilimsel nitelik

\footnotetext{
42 Güran, 1976, 78.

43 Güran, 1976, 132-33.

44 Bilecik, 1998, 49-50.

45 Daha detaylı bilgi için $b k$. Ersoy, 1991; Ahunbay, 2005, 205-211; Ersoy \& Uçar, 2015, 39-58.

46 Yayında, “Serpos Han'da bir odanın tavan süslemesi” şeklinde bir açıklama ile yer almıştır. Bk. Öncel, 2010, 110.
} 
taşımayan bir internet yayınında da yer almıştır. ${ }^{47} \mathrm{Bu}$ yayında resmin Galileo'yu betimlediği belirtilmektedir. Resimde kullanılan bazı nesneler bu kanıyı güçlendirse de benzer ve açık bir örnek bulunamadığından bu kanının doğruluğu tartışmaya açıktır. Batı dünyasında Galileo'yu resmeden çalışmalarda da benzer nesnelerin kompozisyonda yer aldığ tespit edilmiştir. (Ör. bk. Fot. 29$)^{48}$ Bu tablolarda; figürün çalışma ortamı, giyimi gibi bazı detaylar, Serpuş Han'daki resimle önemli farklılıklar göstermektedir.

Serpuş Han'da bilginin tasvir edildiği resimde, resmin altında yer alan armanın hangi topluluğa ait olduğu tespit edilememiştir. En yakın benzeri günümüzde bir koleksiyonda bulunan ve 1890 yilına ait Fransız işi olduğu belirtilen ahşap malzeme üzerine yapılmış armadır. (Fot. 28) Koleksiyondaki eserde ortadan bir çizgiyle ikiye ayrılmış armanın karşıdan bakıldığında solunda Latin haçı, sağında üstte bir kuş figürünün bulunması önemli bir benzerliğe işaret etmektedir. Sağ altta boyalar döküldüğünden o kısımda ne olduğu anlaşılamamıştır. Serpuş Han'daki resimde ise sağ altta çatılmış iki kılıcın yer aldığı görülmektedir. (Fot. 27)

Dikdörtgen formlu ve merkezinde Barok üslupta bitkisel bezemelerin yer aldığı resim, Büyük Yeni Han'ın (1764-64) bazı odalarının duvar ve tavan resimleriyle ${ }^{49}$ ve Topkapı Sarayı Harem Dairesi'nde yer alan Barok-Rokoko üslubundaki duvar ve tavan resimleriyle ${ }^{50}$ üslup açısından karşılaştırılabilir. Burada tasarımlar birebir benzemese de form ve motiflerin ele alınışları bakımından birtakım benzerlikler belirtilebilir.

Tavan resimlerinin 18. ve 19. yy.'dan kalmış olabileceğini düşünmekteyiz. 1895 ile 1914 tarihleri arasında handa çalışan esnaflar ve yaptıkları işlerle ilgili bilgiler sunan çalışmada ${ }^{51}$ verili listede antikacı, litograf, kitapçı gibi meslek erbaplarının önemli oranda Avrupalı oluşu, özellikle bilginin tasvir edildiği tavan resmini yapanlar hakkında bir fikir verebilir.

47 Bk. Cornucopia, 2019. Sitede, “Serpuş Han” başlığı altında biri bu resim olmak üzere iki fotoğraf verilmiş, kısaca yapının konumu, tavan resminin Galileo’yu betimlediği belirtilmiştir.

48 Fotoğraflar için $b k$. Wikimedia, 2020.

49 Bk. Bildik, 1968, 3316; Eyice (1992), 518. Bu iki çalışmada bahsedilen tavan ve duvar resimlerine dair görsel kullanılmamıştır. Ancak, Demirçivi’nin makalesinde Büyük Yeni Han'daki bir odanın duvar ve tavan resimlerine yer verilmiştir. Bk. Demirçivi, 2000, 157-170; Okçuoğlu, 2017, 170-173.

50 Bk. İrez,1990, 21-54. Bu kaynakta ağılıklı olarak 18. yy. ikinci yarısında hüküm süren padişahların dönemlerinde yapıldığı değerlendirilen Rokoko üslubunda örnekler bulunmaktadır.

51 Fidan, 2005, 59. 


\section{KAYNAKÇA}

Ağır, A. (2009). İstanbul'un Eski Venedik Yerleşimi ve Dönüşümü, İstanbul: İstanbul Araştırmaları Enst. Yay.

Ahunbay, (2005). Decorative Coatings on Some Eighteenth Century Buildings in Istanbul, Afife $\quad$ Batur'a Armağan, 205-211.

Akın, N. (1998). 19. Yüzyılın İkinci Yarısında Galata ve Pera, İstanbul: Literatür Yay.

Akis, M. (2014). Osmanlı Denizcilik Tarihi Açısından 1124H./1712M. Tarihli Ahidname ve 18. Yüzyıl Başarında Osmanlı- Ceneviz İlişkileri, Uluslararası Piri Reis ve Türk Denizcilik Tarihi Semp. Bildirileri 26-29 Eylül 2013, Ankara: Türk Tarih Kurum Yay., Cilt:4, 1-16.

Akozan, F. (1963). Türk Han ve Kervansarayları, Türk San'atı Tarihi Araştırma ve İncelemeleri I, İstanbul, 133-167.

Arseven, C.E. (1989a). Eski Galata ve Binalarl, (Haz. Dilek Yelkenci) İstanbul: Çelik Gülersoy Vakfı Yay.

Arseven, C.E. (1989b). Eski İstanbul, (Haz. Dilek Yelkenci) İstanbul: Çelik Gülersoy Vakfi Yay.

Arslan, H. (2005). Osmanl Mimarisinde Ahşap Tavan Göbekleri, İstanbul Üniversitesi, Sosyal Bil. Enst., (Yayımlanmamış Yüksek Lisans Tezi).

Bareilles,B. (2003). Istanbul'un Frenk ve Levanten Mahalleleri, (Çev. Ali Berktay), İstanbul: Güncel Yay.

Beylié, L. (1903). L'habitation Byzantine-Les Anciennes Maisons de Constantinople, Paris: Grenoble: H. Falque \& F. Perrin.

Bildik, C. (1963). Büyük Yeni Han, İstanbul: R.E.Koçu İstanbul Ansiklopedisi, Cilt 6. 3313-3316.

Bilecik, G. (1998). XVIII. Yüzyıl İstanbul Hanlarında Cephe Kuruluşları, İstanbul Üni. Sosyal Bil. Enst., (Yayımlanmamış Yüksek Lisans Tezi).

Bulunur, K. İ. (2014). Osmanlı Galatası (1453- 1600), İstanbul: Bilge Kültür Sanat Yay.

Cantay, G. (1994). Serpuş Hanı, Dünden Bugüne İstanbul Ans., İstanbul: Tarih Vakfı ve Kültür Bak. Ortak Yay., Cilt:6, 532.

Carbognano, C.C. (1993). 18. Yüzyılın Sonunda İstanbul, İstanbul: Eren Yay.

Ceco, S. (2012). İstanbul'un 100 Hanı, İstanbul: İBB Kültür AŞ. Yay. 
Cornucopia, (2019), Serpuş Han, https://www.cornucopia.net/guide/listings/ sights/serpus-han1/ (Erişim: 24.11.2019)

Cuneo, P. (1989). Recenti Studi Italiani Sull'Architettura di Galata, Quaderni di Ístanbul 2, Roma: Tipografia Don Basco, (Düz. Adelia Rispoli), pp. 49-64.

Çelebi, E. (2003). Günümüz Türkçesiyle Evliya Çelebi Seyahatnamesi: İstanbul, (Haz. S.Ali Karaman-Yücel Dağl1), Cilt:1, 2. Kitap, İstanbul: Yap1 Kredi Yay.

Çelik, Z. (2017). 19. Yüzyılda Değişen İstanbul, İstanbul: İş Bankası Yay. 3. Baskı.

Çobanoğlu, A.V. (2009). Seyyid Hasan Paşa Külliyesi, TDV Íslam Ans., Cilt: 37, 60-62.

Demirçivi, (2012). Un Exemple de Peintures Murales dans le Büyük Yeni Han a İstanbul, İstanbul Araştırmaları Yıllı̆̆gl, Sayı:1, 157-170.

Erksan, M. (1956). İstanbul Hanları, İstanbul Üniversitesi, Edebiyat Fak., Sanat Tarihi Bölümü, (Yayımlanmamış Lisans Tezi).

Eroğlu, A. Ö. (1993). Bir Ceneviz Kolonisinden İzler, İstanbul: İstanbul İtalyan Kültür Merk. Yay.

Ersoy, B. (1991). İzmir Hanları, Ankara: Atatürk Kültür, Dil ve Tarih Yüksek Kurumu Atatürk Kültür Merkezi Yay.

Ersoy, B. (1994). Osmanlı Şehir-İçi Hanları Plan Tasarımı ile Cephe ve Malzeme Özellikleri, Sanat Tarihi Dergisi, 8, 75-97.

Ersoy, E. \& Uçar, H. (2015). Şehir-içi Hanlarında Süsleme, Prof. Dr. Selçuk Mülayim Armağanı Sanat Tarihi Araştırmaları, İstanbul: Lale Yay., 39-58.

Eyice, S. (1969). Galata ve Galata Kulesi, İstanbul: TTOK Yay.

Eyice, (1991), Atıf Efendi Kütüphanesi-Mimari, TDV İslam Ans., Cilt: 4, 61.

Eyice, S. (1992). Büyük Yeni Han, İstanbul: TDV Íslam Ansiklopedisi, Cilt: 6, 518-519.

Eyice, S. (2009). Eski İstanbul'dan Notlar, Küre Yay., 3. Bask1.

Fidan, S. (2009). Geçmişten Günümüze İstanbul Hanları, İstanbul: İTO Yay.

Güran, C. (1976). Türk Hanlarının Gelişimi ve İstanbul Han Mimarisi, İstanbul: VGM Yay.

Horoz, M.A. (2019). 17. Yüzyıl Başlarında Galata'ya Gelen Ticari Ürünler ve Galata Gümrük Bölgesi, Anasay, 7, 137-156. 
İrez, F. (1990), Topkapı Sarayı Harem Bölümü'ndeki Rokoko Süslemenin Batıl1 Kaynakları, İstanbul: Topkapı Sarayı Müzesi Yıllı̆̆gl, Cilt:4, 21-54.

Kallek, C. (2000). İmtiyâzât, TDV İslam Ans., Cilt: 22, 242-245.

Kuş, F. (2009). Galata Surları, Marmara Üni., Türkiyat Araştırmaları Enst., (Yayımlanmamış Yüksek Lisans Tezi), İstanbul.

Neligan, D. (2017-2020), Two European Carved And Painted Oak Coast Of Arms, David Neligan Antiques: http://www.davidneliganantiques.com/ product/two-european-carved-painted-oak-coats-arms/) (Erişim 27.01.2020)

Okçuoğlu, T. (2017), Hayalle Gerçek Arasında Osmanlı Resminde İstanbul İmgesi (XVIII-XIX Yüzylllar), İstanbul: Ofset Yapımevi Yay.

Ortayl1, O. (1968). İstanbul (Tarihi Eserler)-Galata, MEB İslam Ansiklopedisi, MEB Yay., Cilt:5/2, 1214/144-1215/157.

Ortayl1, O. (1996). Galata, TDV İslam Ans., Cilt:13, 303-307.

Öncel, A.D. (2010). Apartmanlar Galata'da Yeni Bir Konut Tipi, İstanbul: Kitap Yay.

Özkan, N. (200). Venedik Senatosu Sekreteri Pietro Busenello'nun İstanbul Gözlemleri (1742 - 1746) 'Lettere Informatıve Delle Cose De' Turchi, İstanbul: Osmanlı Araştırmalarl, $\quad$ Sayı: 20， 269294.

Refik, A. (1988). Hicri Onikinci Asırda İstanbul Hayatı (1100-1200), İstanbul: Enderun Yayınları.

Wellcomecollection, (2020), Galileo Galilei (1564-1642) Oil painting by an Italian painter, 18th (?) century., https://wellcomecollection.org/ works/v6ux23p7/items (Erişim: 27.01.2020.)

Wikimedia, (2020), Paintings of Galileo Galilei, https://commons.wikimedia. org/ wiki/Category:Paintings_of Galileo_Galilei (Erişim: 27.01.2020.)

Yaşar, A. (2014). İstanbul Hanları- 18. Yüzyıl Sonu ve 19. Yüzyıl Baş1, İstanbul: I. Uluslararası Osmanlı İstanbulu Sempozyumu Bildiriler, 29 Mayıs-1 Haziran 2013, (Ed. Feridun Emecen vd.), İBB Yay., 511524. 


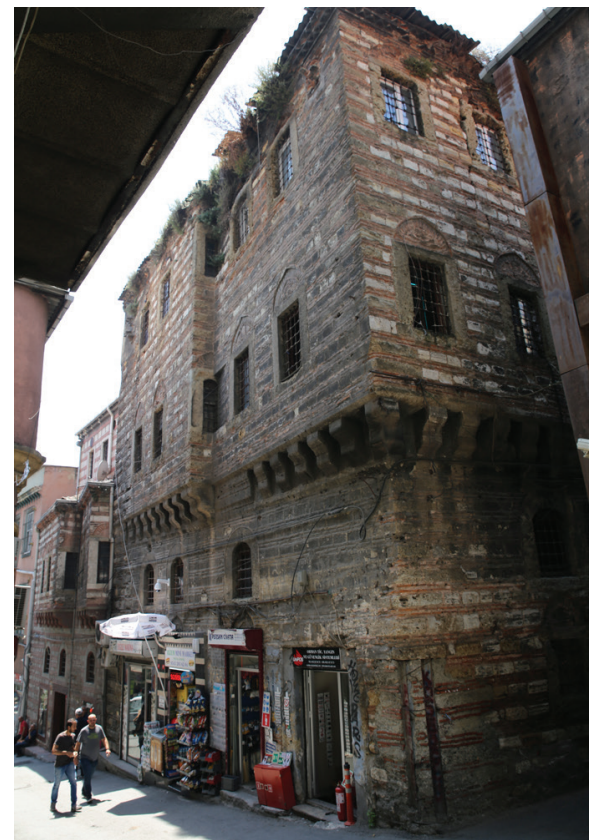

Fot. 1: Hanın Doğudan Genel Görünümü

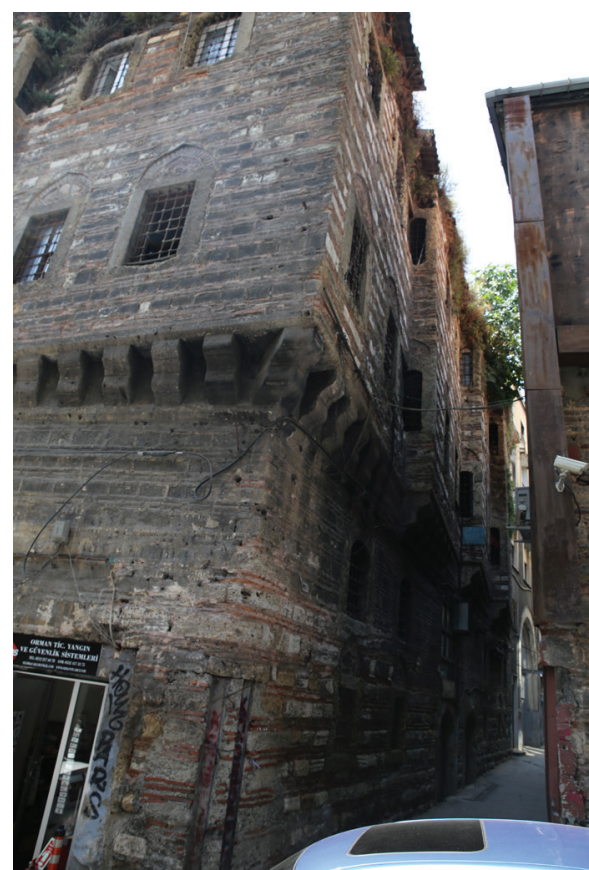

Fot. 3: Cadde Tarafından Eski Tay Çıkmazı

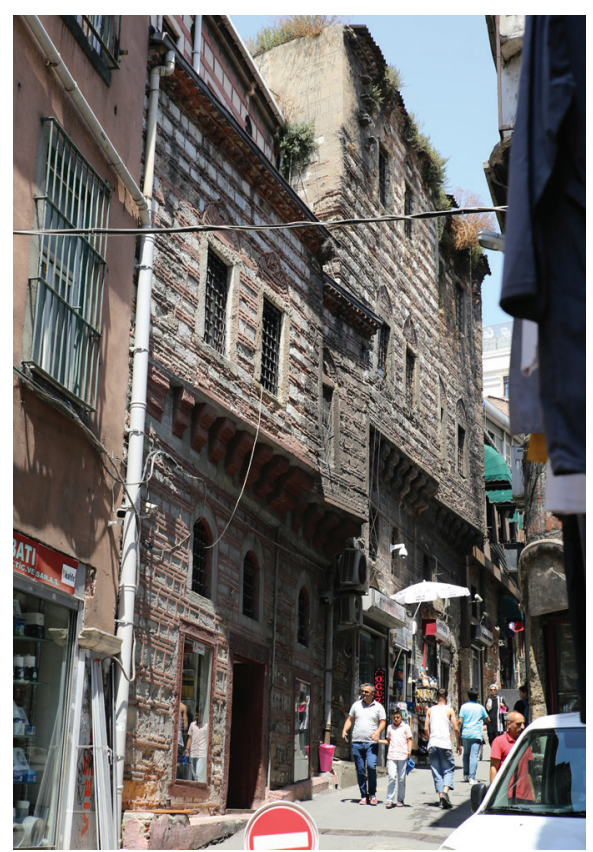

Fot. 2: Hanın Güneyden Genel Görünümü

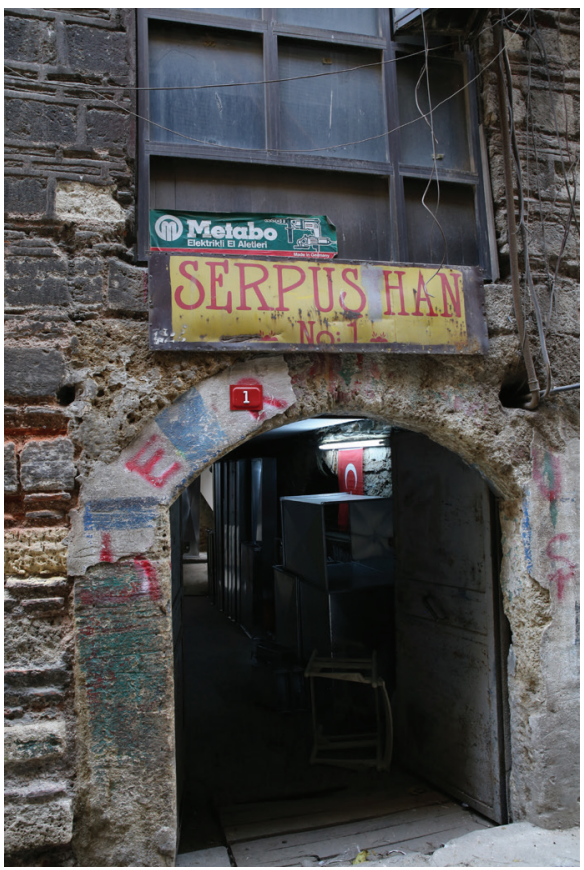

Fot. 4: Hanın Girişi 


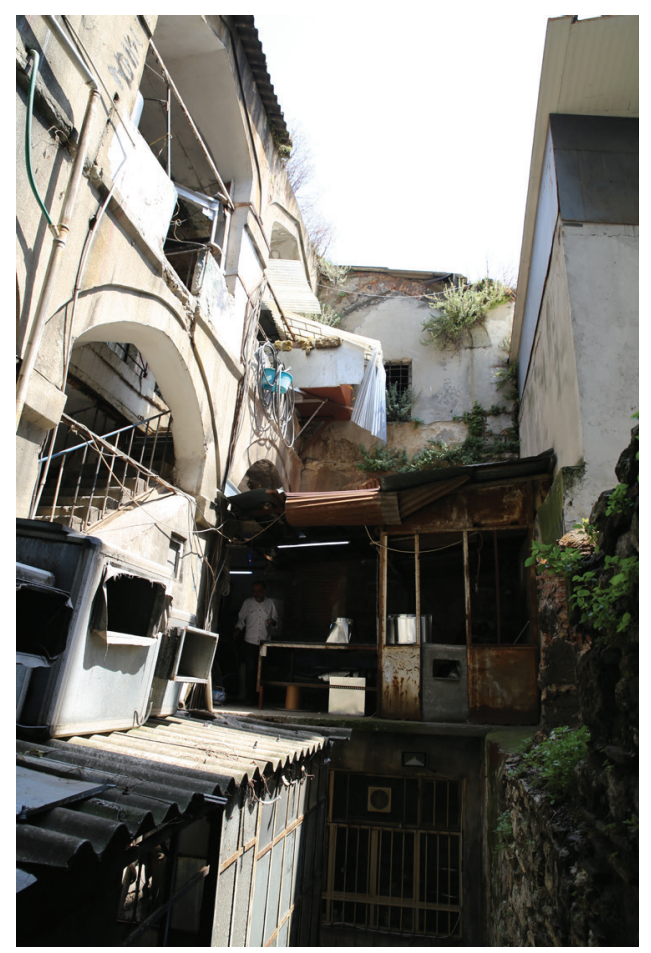

Fot. 5:

Avludan Revakların

Görünümü

$\nabla$ Fot. 6: Profilli Taş

Konsollara Oturan Çıkmalar

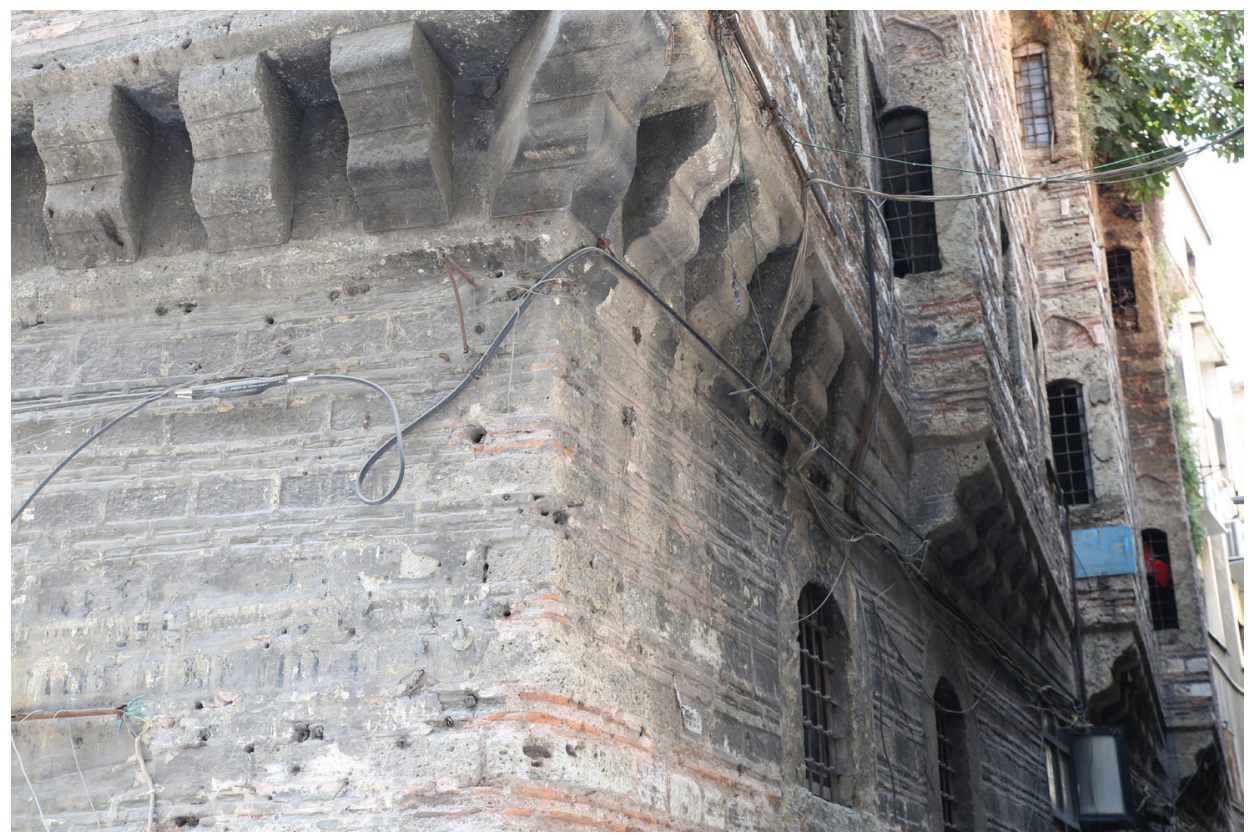




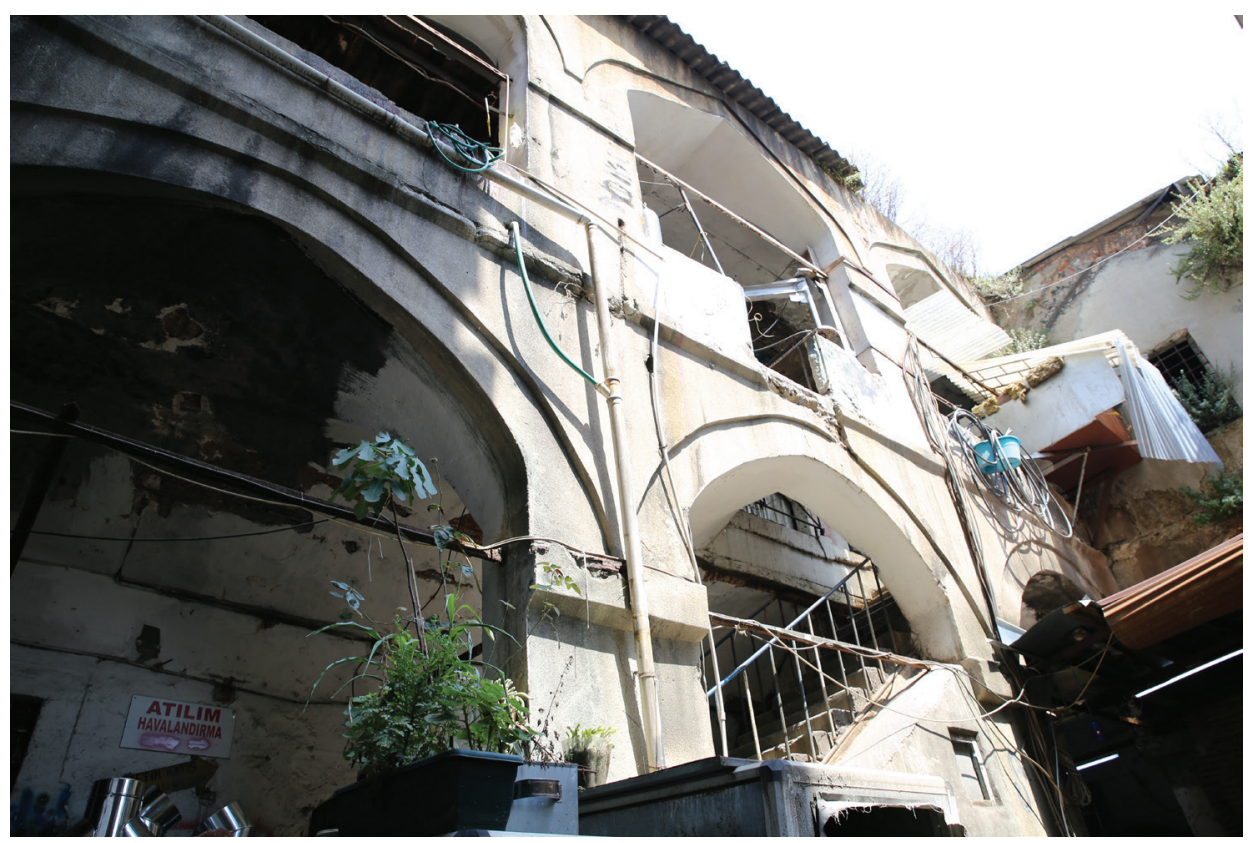

Fot. 7: Revaklar

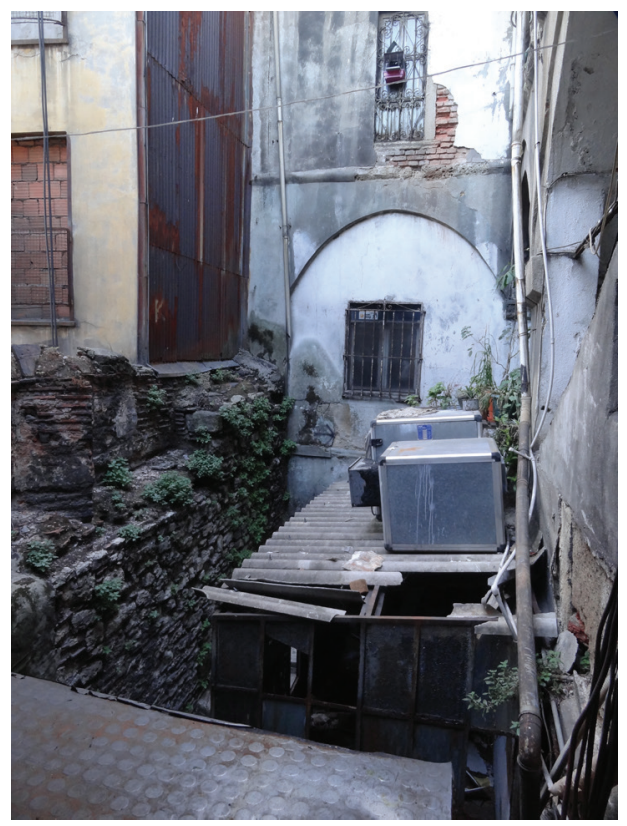

Fot. 8: Avlu ve Kapatılan Revak Kisımları

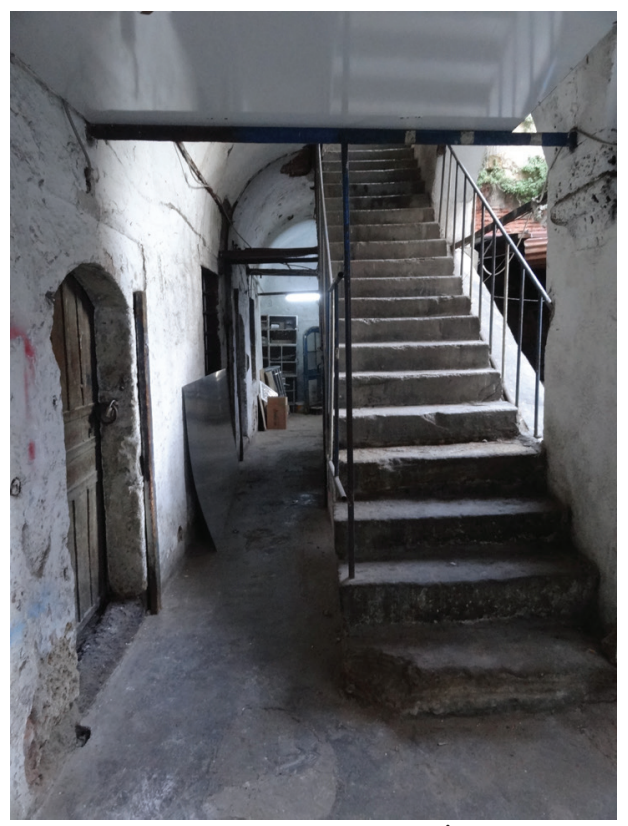

Fot. 9: Birinci Kat Revağından İkinci Kata Çıkan Merdiven 

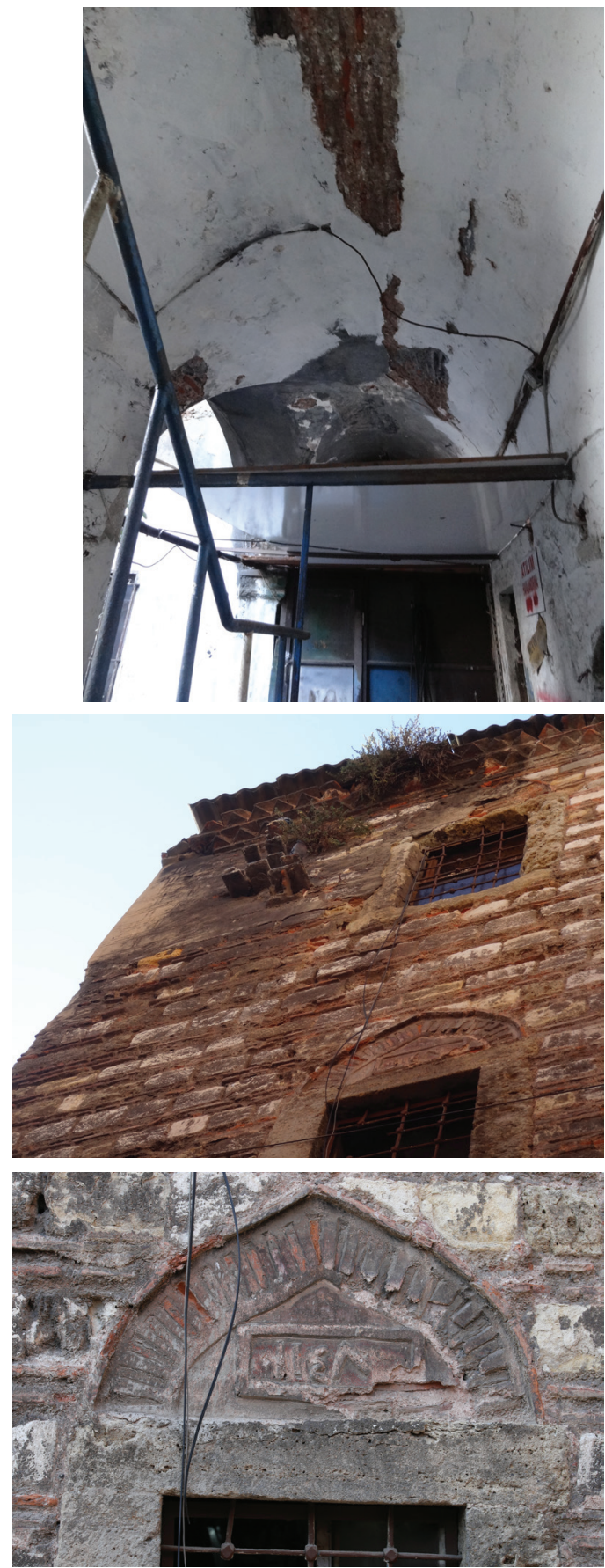

Fot. 10: Revağın Üst Örtüsü Tonoz

Fot. 11: Tarih Kitabeli Pencere Alınlığ1 ve Kuş Evinin Kalan Kısmı

Fot. 12: Birinci Kat Pencere Alınlığ Tarih Kitabesi 


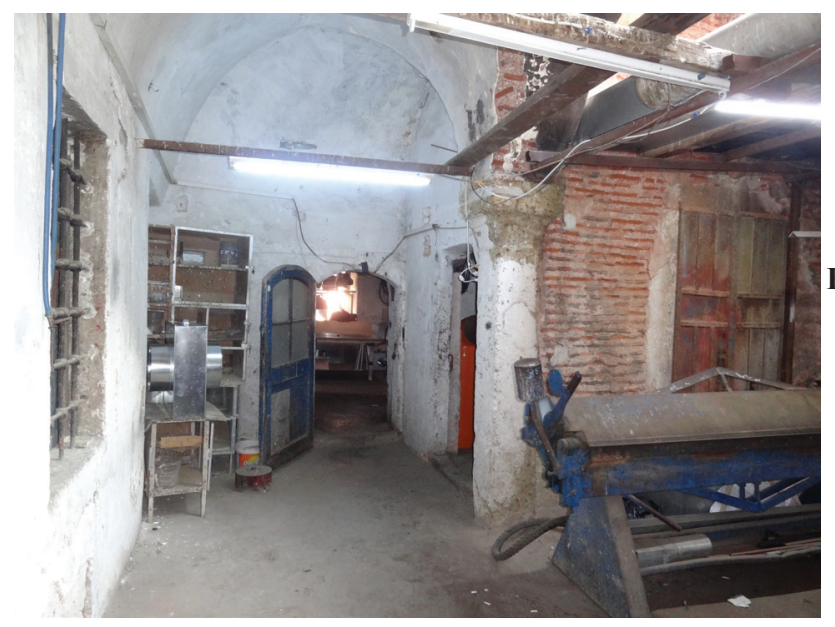

Fot. 13: Birinci Kat

Revağında

Odaların Girişi

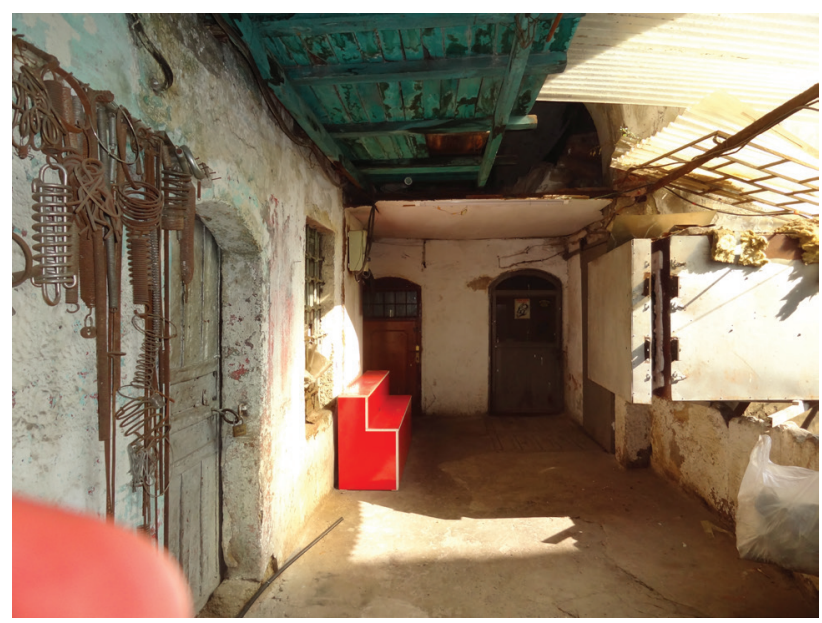

Fot. 14: İkinci Kat

Revağında

Odaların Girişi

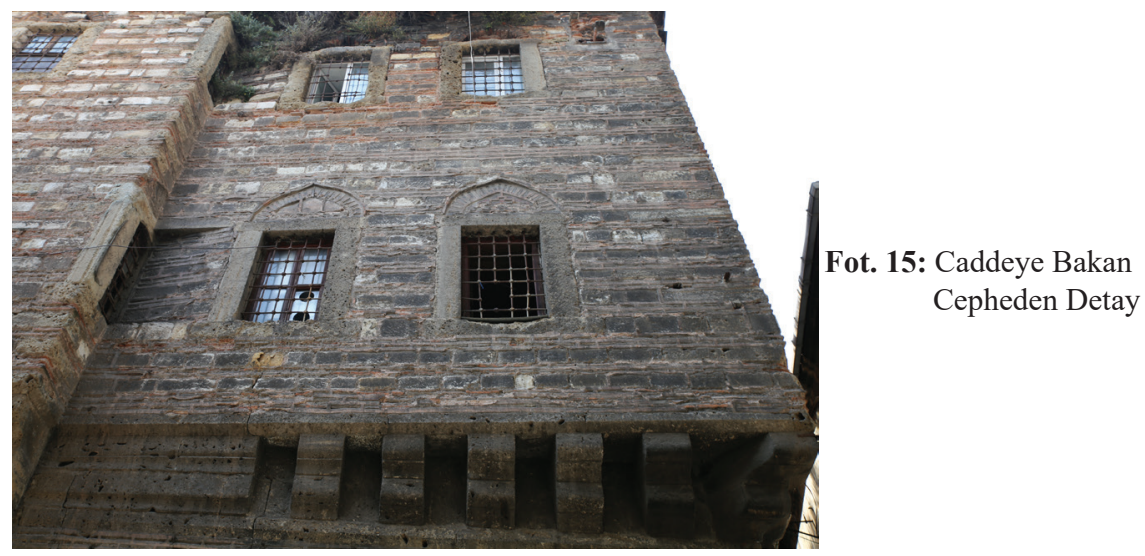



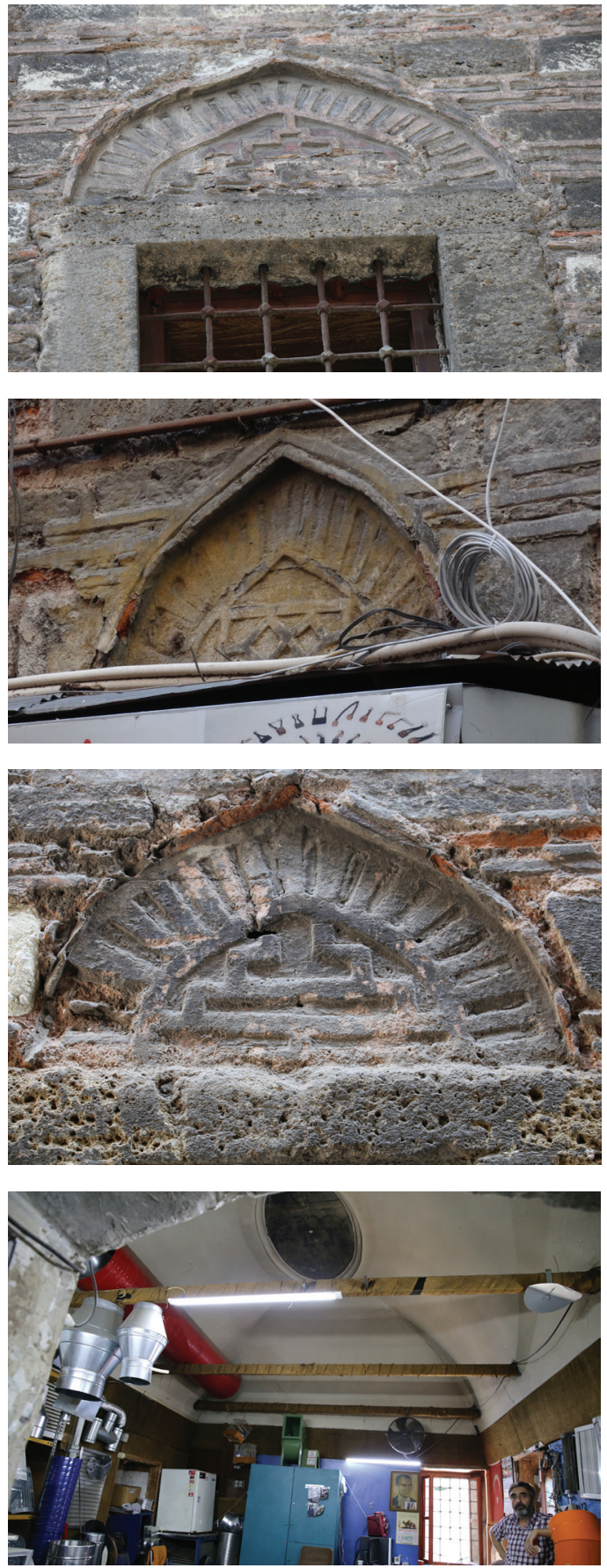

Fot. 16: Caddeye Bakan

Cephede Pencere Alınlığında Merdiven Motifi

Fot. 17: Caddeye Bakan Yüzde Zemin Kat Pencere Alınlığında Geometrik Motif

Fot. 18: Eski Tay Çıkmazı Zemin Kat Pencere Alınlığ 1

Fot. 19: Eliptik Madalyon İçindeki Resmin Bulunduğu Oda 


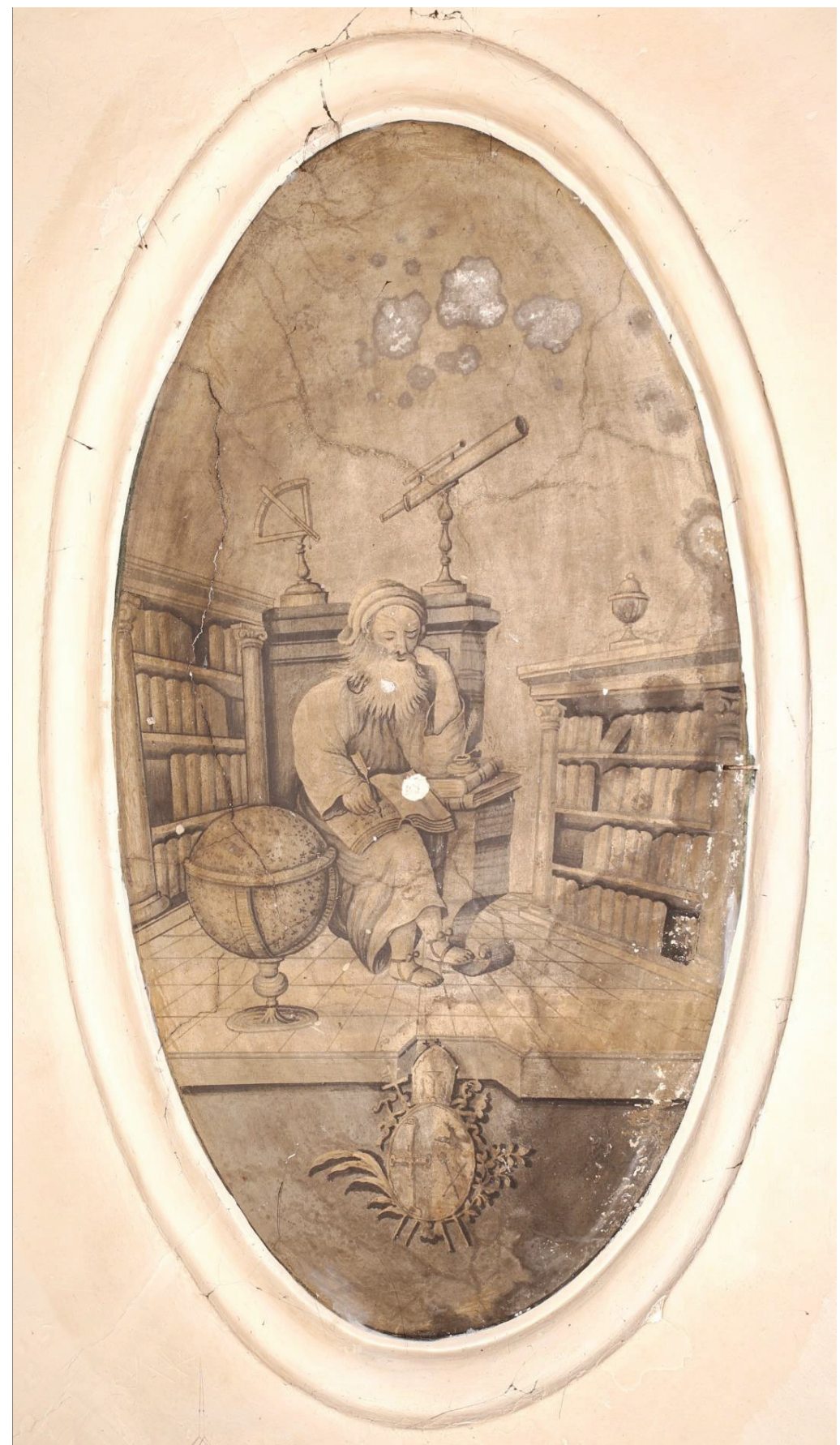

Fot. 20:

Birinci Kat

Köşe Oda

Tavan Resmi 


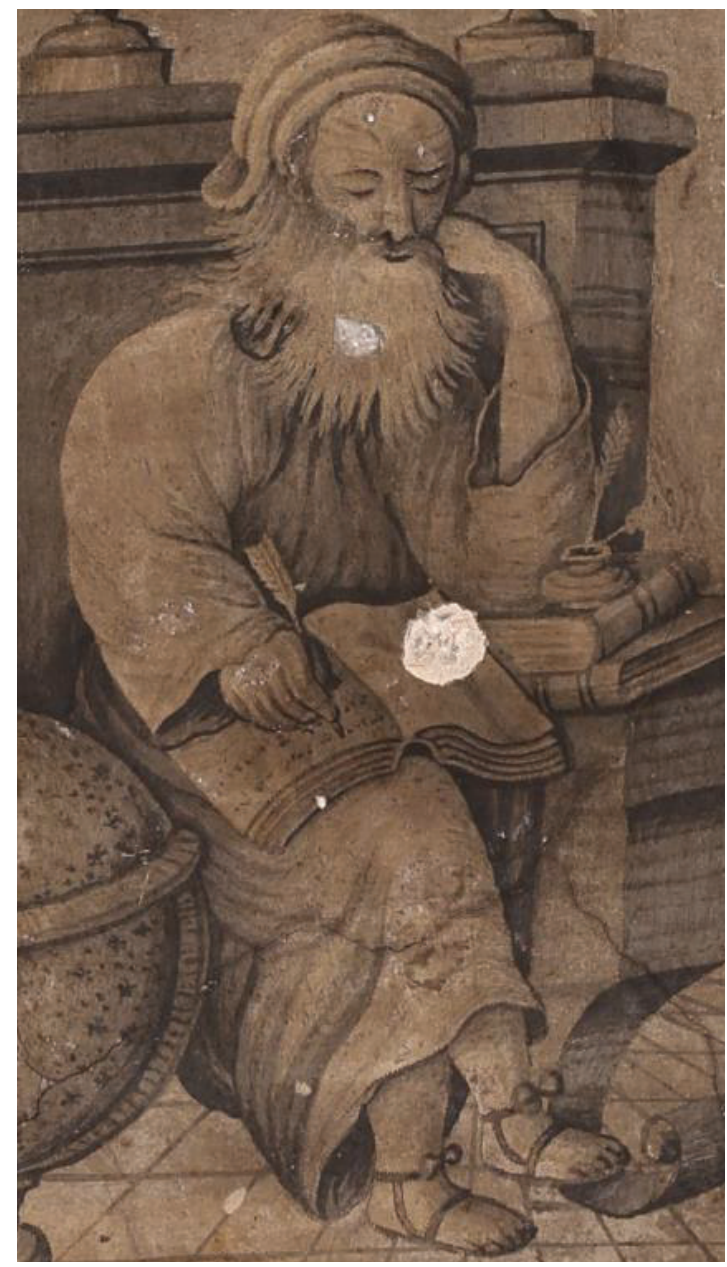

Fot. 21:

Birinci Kat Köşe Oda

Tavan Resmi, Detay

Fot. 22:

Birinci Kat Köşe

Oda Tavan Resmi, Detay

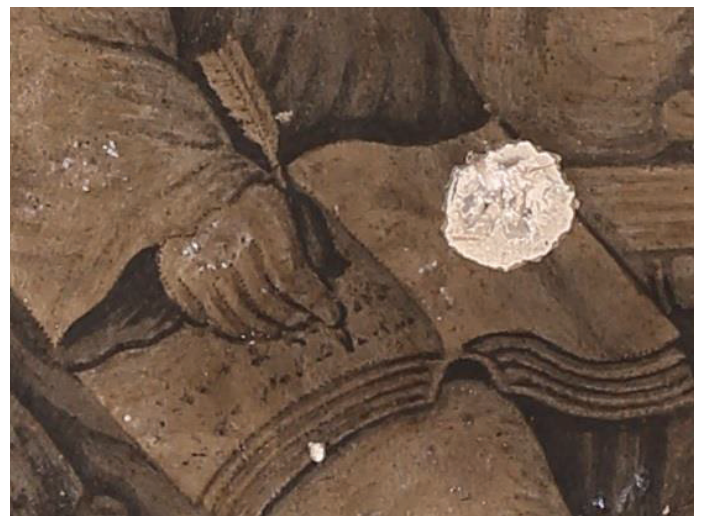




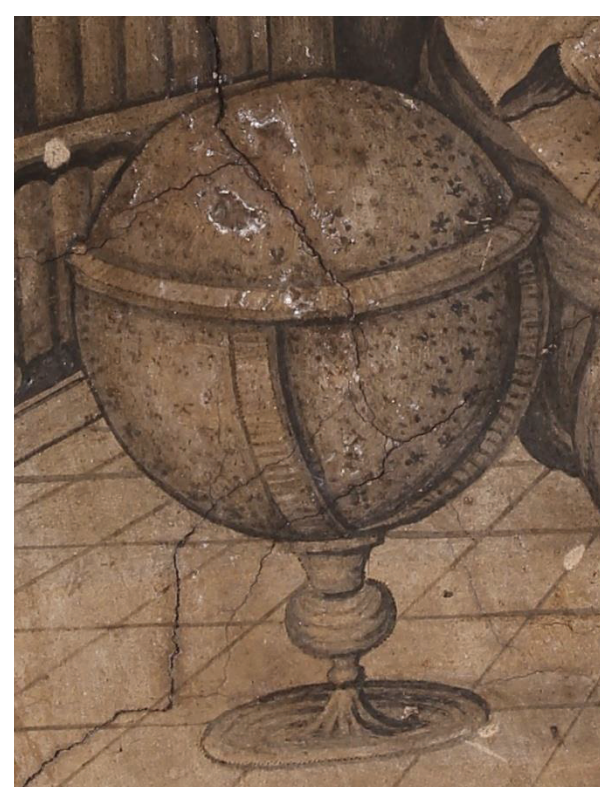

Fot. 23: Birinci Kat Köşe Oda Tavan Resmi, Detay (Küre)

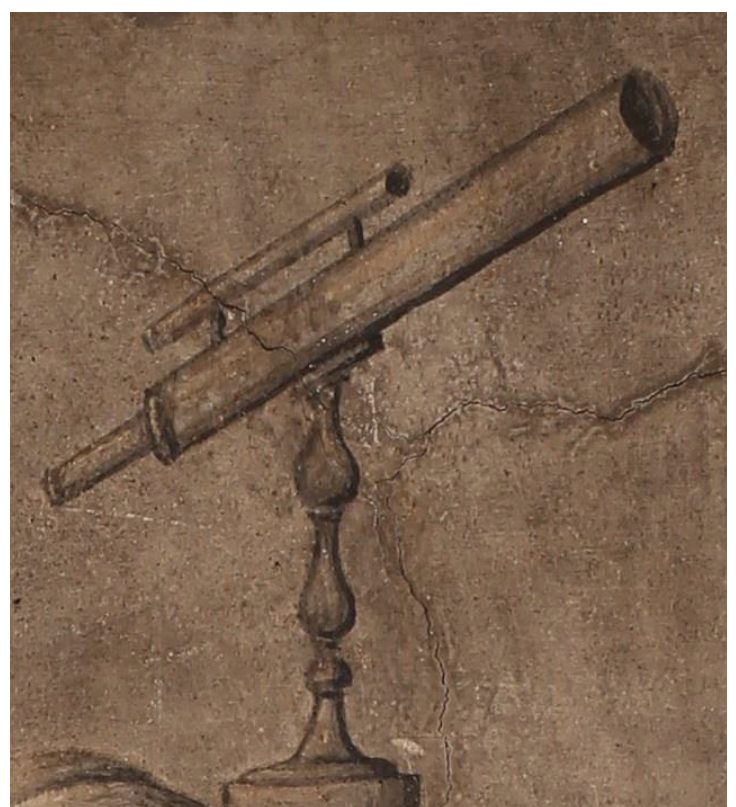

Fot. 25: Birinci Kat Köşe Oda Tavan Resmi, Detay (Teleskop)

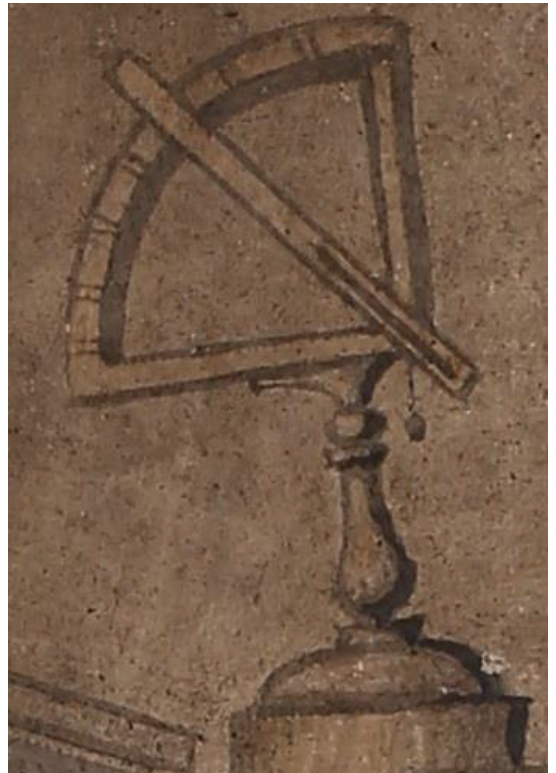

Fot. 24: Birinci Kat Köşe Oda Tavan Resmi, Detay (Açıölçer)

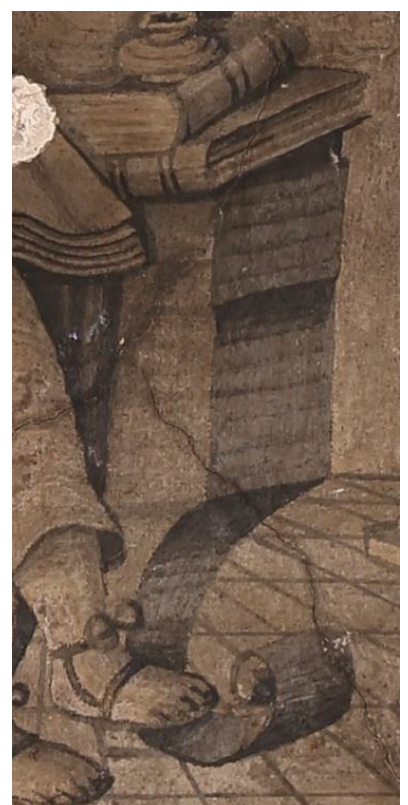

Fot. 26: Birinci Kat Köșe Oda Tavan Resmi, Detay (Sehpa) 


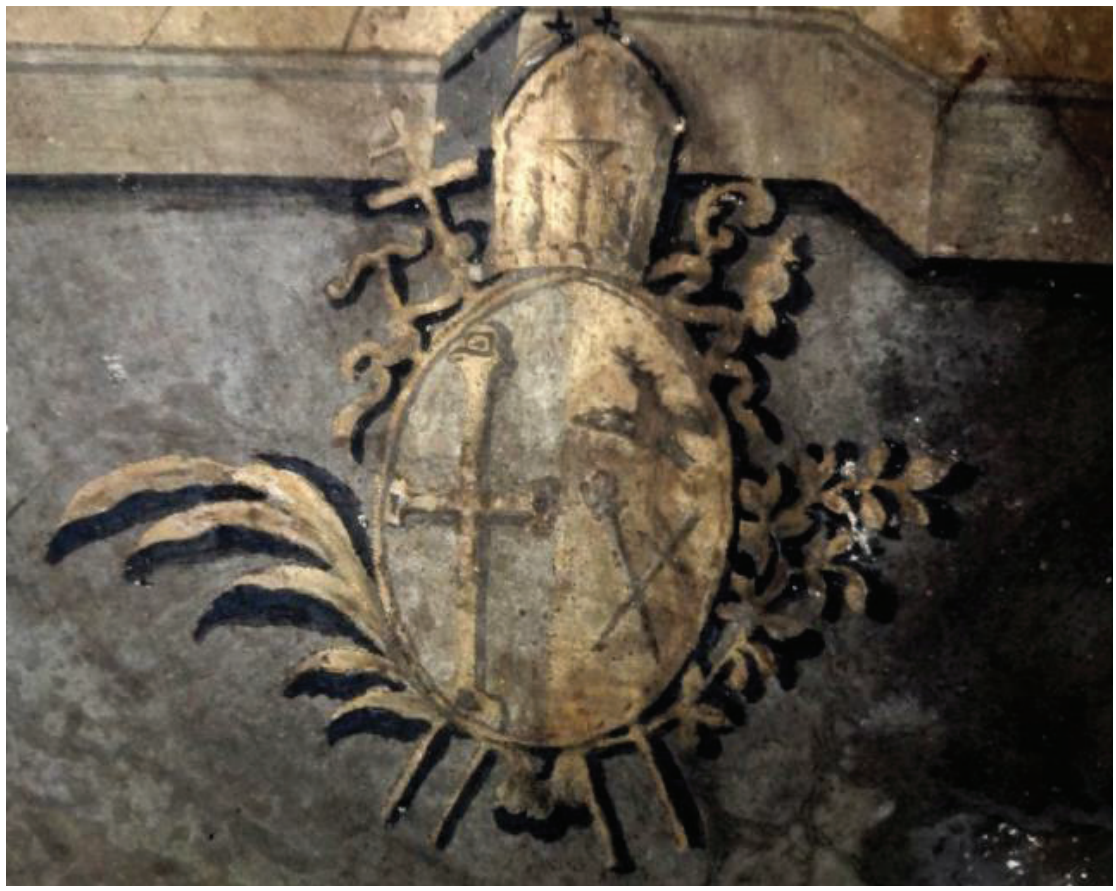

Fot. 27: Birinci Kat Köşe Oda Tavan Resmi, Detay (Arma)

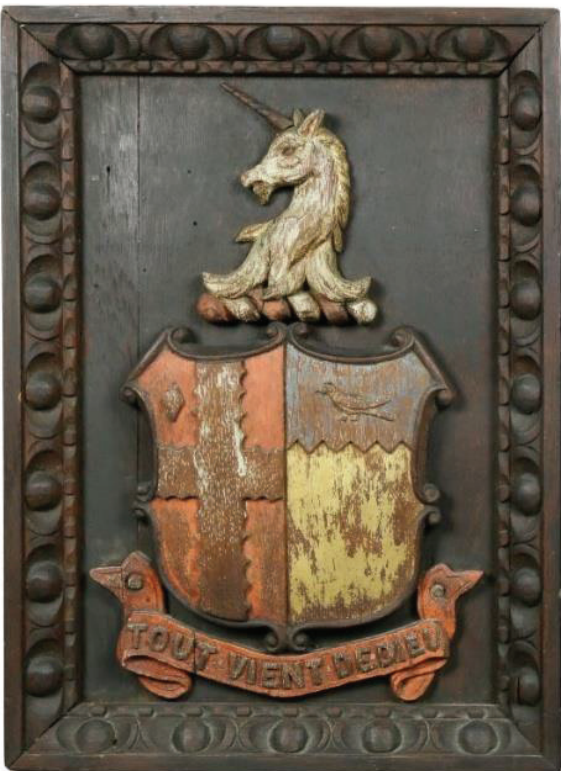

Fot. 28: 1830 Tarihli ve Fransız Menşeli Olduğu Belirtilen Ahşap Arma (Neligan 2017-2020)

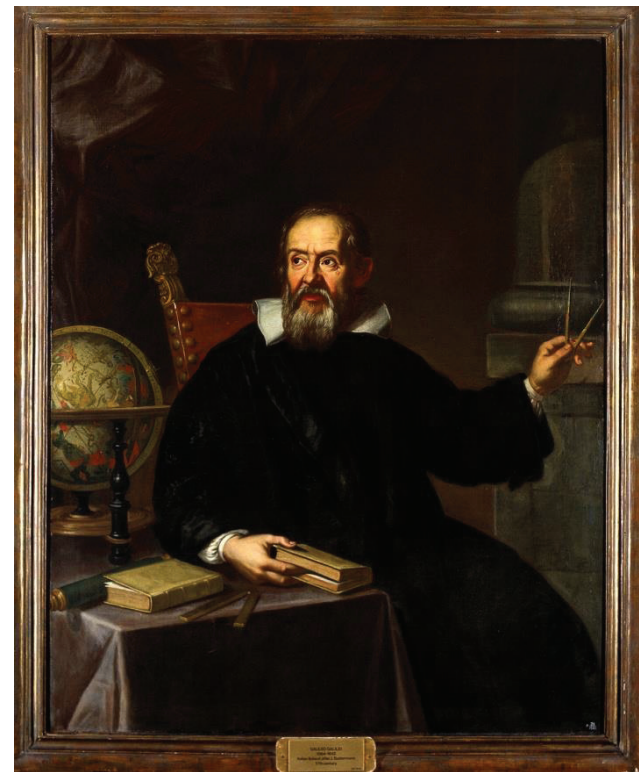

Fot. 29: Galileo Galilei. 18. yy'da İtalyan Bir Ressamın Yaptığı Düşünülen Bir Tablo. Tuval üzerine yağlıboya. (Welcome Colection, 2020)] 


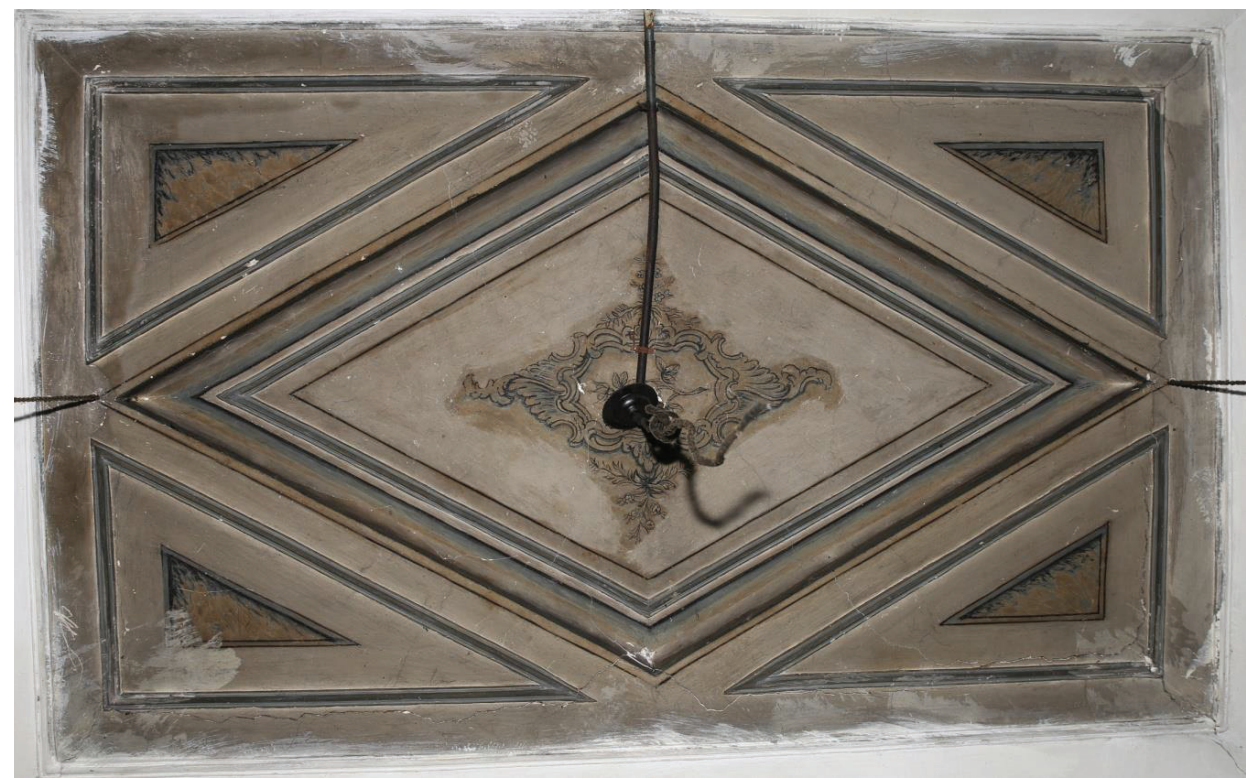

Fot. 30: Eski Tay Çıkmazı'na Bakan Odadaki Tavan Resmi

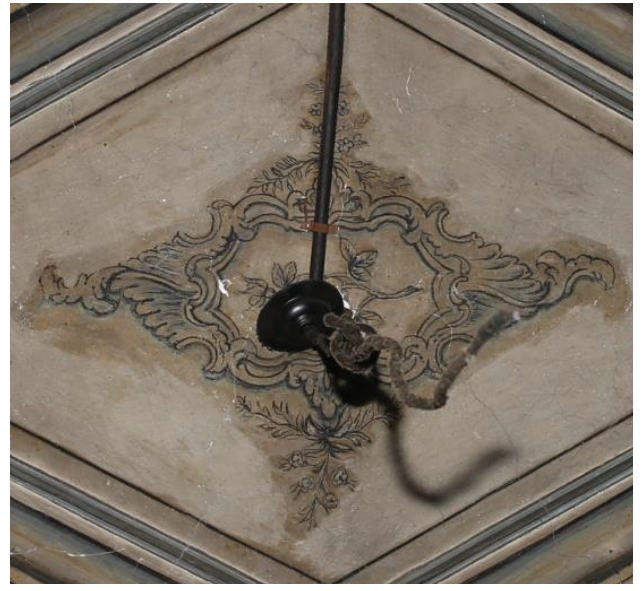

Fot. 31: Tavan Resmi, Detay

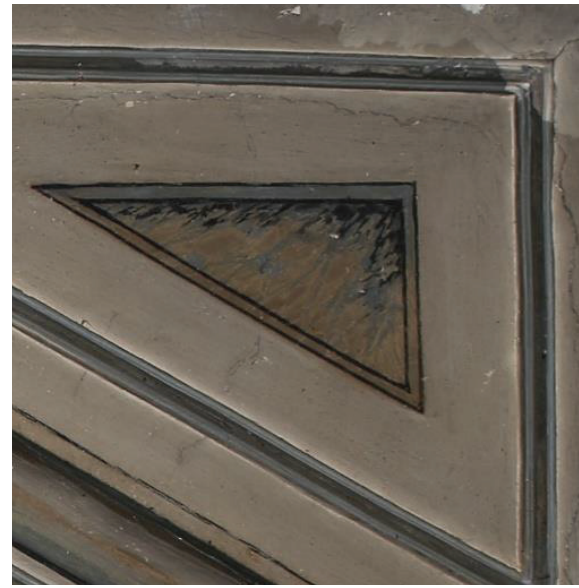

Fot. 32: Tavan Resmi, Detay 


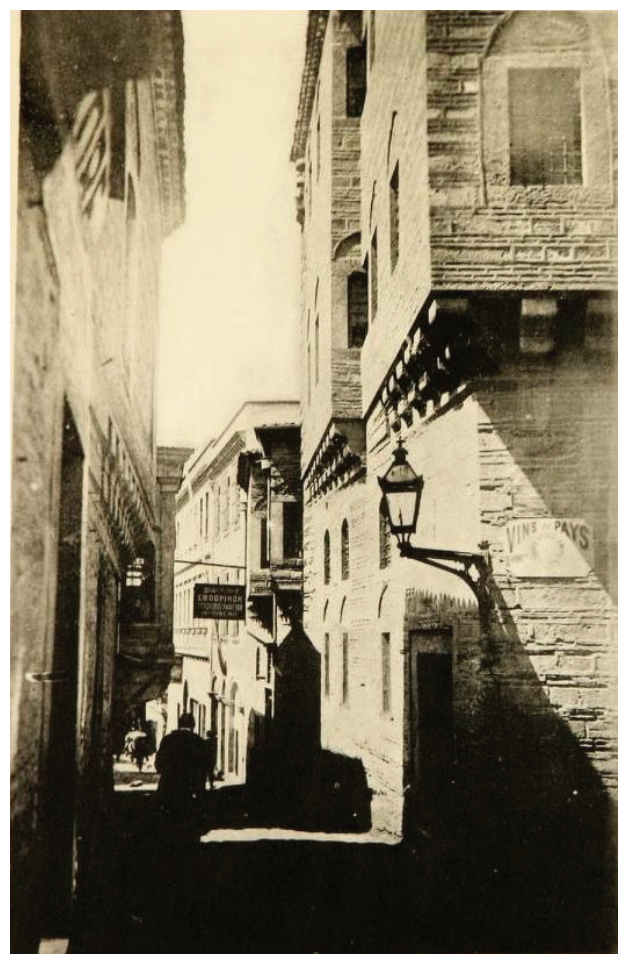

\section{Fot. 33:}

20. yy. Başlarında

Perşembe Pazarı Caddesi,

(Beylié, 1903, X)

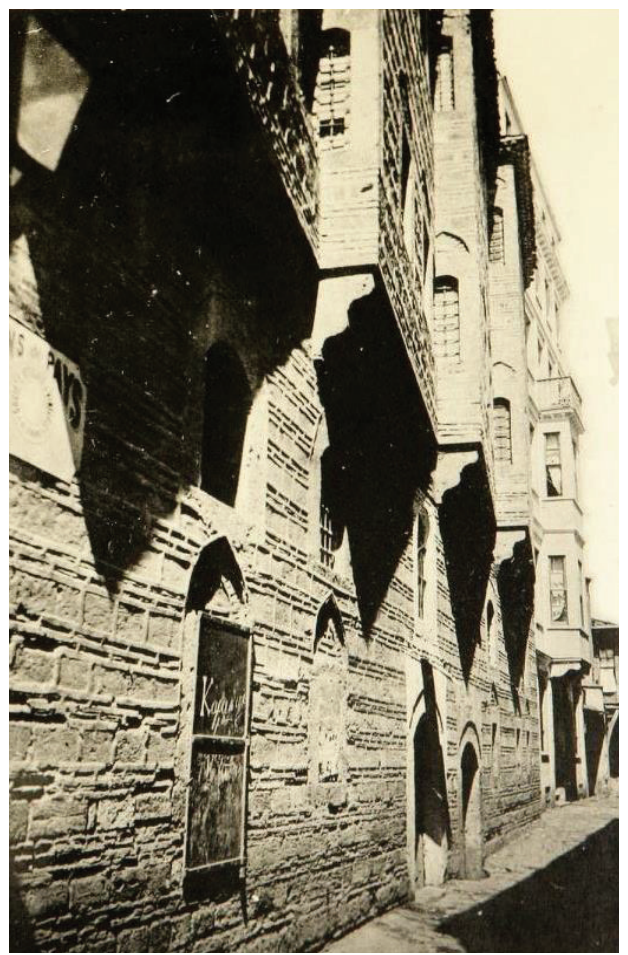

Cephesi, 20. yy. Baş1 (Beylié, 1903, X) 
Ege Üniversitesi, Edebiyat Fakültesi Sanat Tarihi Dergisi

ISSN $1300-5707$
Ege University, Faculty of Letters

Journal of Art History

e-ISSN 2636-8064

Cilt: XXIX, Say1: 1 Nisan 2020 | Volume: XXIX, Issue: I April 2020

\section{Internet Sayfası (Ackk Erisim) | Internet Page (Open Access)}

\section{DergiPark}

https://dergipark.org.tr/std

Sanat Tarihi Dergisi hakemli, bilimsel bir dergidir; Nisan ve Ekim aylarında olmak üzere yılda iki kez yayınlanır.

Lournal of Art History is a peer-reviewed, scholarly, periodical journal published biannually, in April and October. 